\title{
Laboratory and Service Tests of Hand Luggage
}

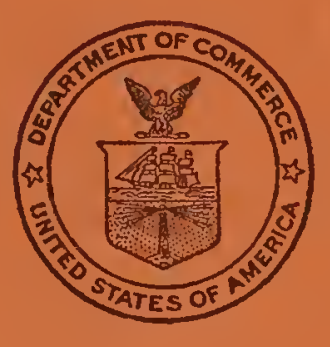

\section{United States Department of Commerce}

National Bureau of Standards

\author{
Miscellaneous Publication 193
}



UNITED STATES DEPARTMENT OF COMMERCE - Charles Sawyer, Secretary NATIONAL BUREAU OF STANDARDS - E. U. Condon, Director

\section{Laboratory and Service Tests of Hand Luggage}

by Edward T. Steiner, Robert B. Hobbs, and Elizabeth R. Hosterman

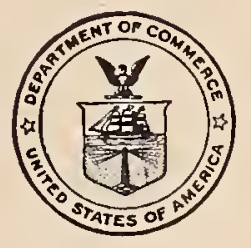

National Bureau of Standards Miscellaneous Publication 193 Issued July 1, 1949

For sale by the Superintendent of Documents, U. S. Government Printing Office, Washington 25, D. C. Price 15 cents 


\section{PREFACE}

The durability of hand luggage is often a matter of serious concern for nearly every traveler, as well as for manufacturers and distributors of luggage and for the transportation industries. Yet when representatives of the railroads, busses, and air lines asked the National Bureau of Standards for assistance in preparing a commercial standard for this commodity, it was found that there existed practically no reported research on the subject. For this reason the Bureau conducted a survey of luggage in service, in bus and railroad stations in 10 cities, to get information needed in developing performance tests for hand luggage.

The findings of the surveys, showing the materials and types of luggage occurring most frequently, the general condition of luggage in service, and the loaded weights of bags in service, are presented in this report. The three laboratory performance tests suggested by the authors require only rather simple apparatus and yield results of adequate precision. These tests have been shown to correlate well with the behavior of luggage in actual service, and therefore seem suitable for use in a commercial standard.

E. U. Condon, Director. 


\section{Contents}

Preface Pago

I. Purpose and plan of the investigation $\ldots \ldots \ldots \ldots \ldots \ldots$

II. Survey of luggage in actual service $\ldots \ldots \ldots \ldots \ldots$

1. Frequency of types of luggage $\ldots \ldots \ldots \ldots \ldots \ldots \ldots \ldots$

2. Frequency of materials used for outer coverings _._._..... 3

3. Weights of luggage in service $\ldots \ldots \ldots$

4. Condition of luggage in service $\ldots \ldots \ldots \ldots$

5. Types of damage in service $\ldots \ldots \ldots \ldots$

III. Description of luggage used in experiments $\ldots \ldots \ldots \ldots \ldots \ldots \ldots$

1. Types and sizes $\ldots \ldots \ldots \ldots \ldots$

2. Chipboard cases $\ldots \ldots \ldots$

3. Vulcanized fiberboard cases _._.

4. Lower-priced fabric-covered cases _... _._.

5. Higher-priced fabric-covered cases _._. $\ldots \ldots \ldots \ldots \ldots \ldots$

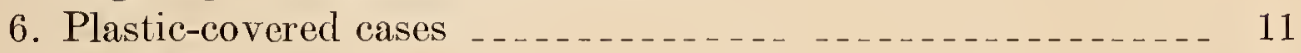

7. Leather-covered cases _............................. 11

IV. Laboratory tests $\ldots$

1. Description of test methods $\ldots \ldots \ldots$

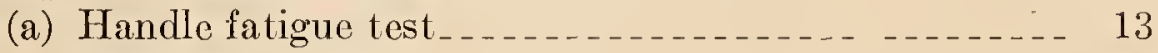

(b) Static load test $\ldots \ldots \ldots$

(c) Divided-table drop test $\ldots \ldots \ldots \ldots \ldots$

(d) Puncture test $\ldots \ldots \ldots \ldots$

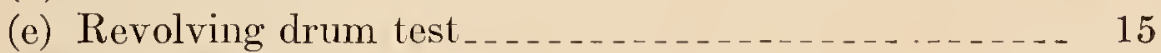

2. Results and discussion $\ldots \ldots \ldots$

(a) Handle fatigue test $\ldots \ldots \ldots$

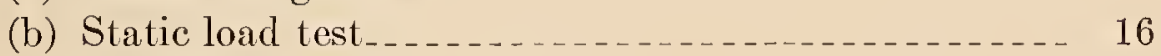

(c) Divided-table drop test_.................. 16

(d) Puncture test_............ 17

V. Service tests

1. Plan of the tests

2. Results $\ldots \ldots \ldots 18$

VI. Conclusions _._.

1. Correlation of laboratory and service tests _._.

2. Recommended requirements _.......... 19 

Lake City. Ttah: Chicago, Ill.: St. Lonis, Mo.; Pittshureh, Par. : Bridgeport and Hartford, Conn.; Trashingion. D. C.: and Tampa and St. Petersbur. Fla. Bagrage in intercity bus stations was smrvered in Pitsburgh, Pa.; Washington, D. C.; and Jicksonville and Tampa, Fla. Observations wore made of baggage passing throngh the Washington National Airport and through La Guardia Field. N. Y., but no data were recorded. In selecting these cities, consideration was given to such variables as geographical location, size of city, and general characteristics of the traveling public and population (industrial, "white collar", or tourist) within the limitations of economy in the survey. The cities ranged in population from about 100,000 to over $3,000,000$. The data obtained are regarded as sufficiently representative to serve as a guide in the development of performance tests designed to evaluate hand luggage.

\section{Frequency of Types of Luggage}

Surveys have been made of 5,804 pieces of luggage in the baggage rooms of railroads in the nine cities. The various styles of luggage in use in the geographic localities represented occur with the percentage frequencies shown in table 1 .

TABLE 1. Frequency distribution of types of luggage in railroad stations

\begin{tabular}{|c|c|c|c|c|c|c|c|c|c|c|}
\hline \multirow{3}{*}{ Typc } & \multicolumn{10}{|c|}{ Locality and number of surveys } \\
\hline & $\begin{array}{c}\text { Wash- } \\
\text { ington, } \\
\text { D. C., } \\
9\end{array}$ & $\begin{array}{c}\text { Bridge- } \\
\text { port, } \\
\text { Conn., } \\
2\end{array}$ & $\begin{array}{c}\text { Hartford, } \\
\text { Conn., } \\
2\end{array}$ & $\begin{array}{c}\text { Salt Lake } \\
\text { City, } \\
\text { Utah., } \\
1\end{array}$ & $\begin{array}{l}\text { Pitts- } \\
\text { burgh, } \\
\text { Pa., } \\
1\end{array}$ & $\begin{array}{c}\text { Chicago, } \\
\text { Jll., } \\
1\end{array}$ & $\begin{array}{c}\text { St. Lou is, } \\
\text { Mo., } \\
1\end{array}$ & $\begin{array}{c}\text { St. Peters- } \\
\text { burg, } \\
\text { Fla., } \\
2\end{array}$ & $\begin{array}{c}\text { Tampa, } \\
\text { Fla., } \\
1\end{array}$ & $\begin{array}{l}\text { All sur- } \\
\text { veys, } \\
20\end{array}$ \\
\hline & \multicolumn{10}{|c|}{ FREQUENCY OF OCCURRENCE-PERCENTAGE OF TOTAL } \\
\hline $\begin{array}{l}\text { Field bag } \\
\text { Suitease } \\
\text { Orernight case } \\
\text { Gladstone bag } \\
\text { Wardrobe ease }\end{array}$ & $\begin{array}{r}3.0 \\
32.1 \\
4.2 \\
6.9 \\
15.2\end{array}$ & $\begin{array}{r}1.3 \\
26.7 \\
2.7 \\
2.7 \\
22.7\end{array}$ & $\begin{array}{r}2.5 \\
29.8 \\
7.4 \\
9.3 \\
13.0\end{array}$ & $\begin{array}{c}3.2 \\
16.1 \\
3.2 \\
0 \\
12.9\end{array}$ & $\begin{array}{r}1.2 \\
38.8 \\
1.2 \\
11.2 \\
18.8\end{array}$ & $\begin{array}{r}0 \\
50.4 \\
2.4 \\
8.1 \\
6.5\end{array}$ & $\begin{array}{r}0 \\
23.8 \\
1.8 \\
3.7 \\
5.5\end{array}$ & $\begin{array}{r}0 \\
32.1 \\
18.9 \\
5.7 \\
24.5\end{array}$ & $\begin{array}{r}0 \\
50.0 \\
3.3 \\
3.3 \\
20.0\end{array}$ & $\begin{array}{r}2.5 \\
32.2 \\
4.4 \\
6.9 \\
14.4\end{array}$ \\
\hline $\begin{array}{l}\text { Hat box } \\
\text { Sample ease } \\
\text { Zipper bag } \\
\text { Boston bag } \\
\text { Valise }\end{array}$ & $\begin{array}{l}0.7 \\
2.1 \\
1.2 \\
0.7 \\
2.3\end{array}$ & $\begin{array}{l}0 \\
4.0 \\
0 \\
2.7 \\
0\end{array}$ & \begin{tabular}{l|}
0 \\
1.9 \\
1.2 \\
0.6 \\
0
\end{tabular} & $\begin{array}{l}0 \\
3.2 \\
0 \\
3.2 \\
0\end{array}$ & $\begin{array}{l}1.2 \\
1.2 \\
1.2 \\
0 \\
2.5\end{array}$ & $\begin{array}{l}1.6 \\
6.5 \\
2.4 \\
1.6 \\
0\end{array}$ & $\begin{array}{c}0 \\
29.4 \\
0 \\
0 \\
0\end{array}$ & $\begin{array}{l}0 \\
0 \\
1.9 \\
1.9 \\
1.9\end{array}$ & $\begin{array}{c}0 \\
0 \\
0 \\
0 \\
10.0\end{array}$ & $\begin{array}{l}0.6 \\
4.1 \\
1.1 \\
0.9 \\
1.7\end{array}$ \\
\hline $\begin{array}{l}\text { "Val-a-pak" } \\
\text { Hand trunk } \\
\text { WVek-end casc } \\
\text { Miseellaneous }\end{array}$ & $\begin{array}{r}1.3 \\
3.4 \\
13.6 \\
13.3\end{array}$ & $\begin{array}{r}2.7 \\
4.0 \\
22.7 \\
8.0\end{array}$ & $\begin{array}{r}3.7 \\
1.9 \\
19.9 \\
8.7\end{array}$ & $\begin{array}{l}0 \\
12.9 \\
19.4 \\
25.8\end{array}$ & $\begin{array}{r}2.5 \\
0 \\
11.2 \\
8.8\end{array}$ & $\begin{array}{r}1.6 \\
0 \\
3.3 \\
15.5\end{array}$ & $\begin{array}{r}0 \\
0.9 \\
5.5 \\
29.4\end{array}$ & $\begin{array}{c}0 \\
0 \\
0 \\
13.2\end{array}$ & $\begin{array}{c}0 \\
0 \\
0 \\
13.3\end{array}$ & $\begin{array}{r}1.5 \\
2.6 \\
12.9 \\
14.3\end{array}$ \\
\hline
\end{tabular}

The classifications used are those appearing on the form used by the Washington (D. C.) Terminal for reporting loss or damage claims. The miscellaneous classification includes such items as previously used paperboard boxes, golf bags, barracks bags, skis, etc.

These results show that three types, namely, week-end and overnight cases (considered as one type), suitcases, and wardrobe cases, are the most fiequently used types in all the cities. They comprise 74.5 percent of all the units surveyed, exclusive of the miscellaneous classification.

The frequencies of occurrence of the types were also tabulated for bus stations in Pittsburgh, Tashington, Tampa, and Jacksonville. The results, fogether with those obtained in the nine railroad stations, are shown in table 2.

The various types appear with approximately the same frequency in bus baggage rooms as in rail baggage rooms except for wardrobe, zipper bag, sample case, and miscellaneous classes. The miscellaneous group, for bus travel, contains a large number of sea and barracks bags, which count appreciably toward increasing the percentage frequency of occurrence over that found in
TABLE 2. Frequency of occurrence of types of luggage in bus and railroad stations (percentage of total for each carrier)

\begin{tabular}{|c|c|c|c|c|c|c|c|}
\hline Carrier & $\begin{array}{c}\text { Field } \\
\text { bag }\end{array}$ & $\begin{array}{l}\text { Suit- } \\
\text { case }\end{array}$ & $\begin{array}{l}\text { Over- } \\
\text { night } \\
\text { case }\end{array}$ & $\begin{array}{c}\text { Glad- } \\
\text { stone } \\
\text { bag }\end{array}$ & $\begin{array}{l}\text { Ward- } \\
\text { robe } \\
\text { case }\end{array}$ & $\begin{array}{l}\text { Hat } \\
\text { box }\end{array}$ & $\begin{array}{l}\text { Sample } \\
\text { case }\end{array}$ \\
\hline $\begin{array}{l}\text { Bus } \\
\text { Railtoad......... }\end{array}$ & $\begin{array}{l}1.9 \\
2.5\end{array}$ & $\begin{array}{l}28.1 \\
32.2\end{array}$ & $\begin{array}{l}2.6 \\
4.4\end{array}$ & $\begin{array}{l}6.4 \\
6.9\end{array}$ & $\begin{array}{r}9.4 \\
14.4\end{array}$ & $\begin{array}{r}0.9 \\
.6\end{array}$ & $\begin{array}{l}0.9 \\
4.1\end{array}$ \\
\hline Carrier & $\begin{array}{l}\text { Zipper } \\
\text { bag }\end{array}$ & $\begin{array}{c}\text { Boston } \\
\text { bag }\end{array}$ & Valise & $\begin{array}{c}\text { Yal-a- } \\
\text { pak }\end{array}$ & $\begin{array}{l}\text { Hand } \\
\text { trunk }\end{array}$ & $\begin{array}{l}\text { Week- } \\
\text { cnd } \\
\text { case }\end{array}$ & $\begin{array}{l}\text { Mis- } \\
\text { cella- } \\
\text { neous }\end{array}$ \\
\hline $\begin{array}{l}\text { Bus } \\
\text { Railroad...... }\end{array}$ & $\begin{array}{l}4.9 \\
1.1\end{array}$ & $\begin{array}{r}0.9 \\
.9\end{array}$ & $\begin{array}{l}1.1 \\
1.7\end{array}$ & $\begin{array}{l}0 \\
1.5\end{array}$ & $\begin{array}{l}3.4 \\
2.6\end{array}$ & $\begin{array}{l}16.5 \\
12.9\end{array}$ & $\begin{array}{l}23.1 \\
14.3\end{array}$ \\
\hline
\end{tabular}

railload service. Zipper bags occur about four times as often in bus stations as in rail terminals. On the other hand, sample cases occur about four times more frequently in the rail terminals.

Nine surveys were made in the Washington Terminal, some on different days of the week, and some at monthly intervals. No significant differences between these surveys were found.

Unlocked bags tend to be more easily damaged than locked ones, because of the possibility of 
covered calses than any other kind except in Chicago, where the proportions of fabric-covered cases and of leather cases are equal. In Salt Lake City fabric-covered bags are not the first choice but have been replaced by metal and fiberboard cases. In bus stations of the four cities surveyed, the filbric cases are the prerlominant type. Pittsburgh oflering the exception, in which locality they are superseded in number by paper-covered baigs and equaled by heary chipboard cases.

Type of material and style are quite closely related in many instances. For example, Gladstone bags are almost always leather, and of nonrigid construction. Occasionally one finds them made of split leather over chipboard. Metal cases are generally of the suitcase size or hand-trunk style. Zipper bags usually appear with canvas covering, rarely in leather or oilcloth.

Table 5 shows, for the principal types of luggage, the percentage of cases of each covering material. Data for other types are available for persons interested in them.

\section{Weights of Luggage in Service}

Overloading is often the cause of damage or failure of a case because of the handle giving way and adds greatly to the shock sustained by a falling case. Therefore, specimens examined during the surveys were weighed, and the over-all volumes of the bags were also measured. Table 6 lists the
TABLE 5. Covering materials for principal types of luggage (Percentage of total for each type)

\begin{tabular}{|c|c|c|c|c|c|c|c|c|}
\hline \multirow[b]{2}{*}{$\begin{array}{l}\text { Type of } \\
\text { baggage }\end{array}$} & \multicolumn{8}{|c|}{ Material } \\
\hline & $\begin{array}{l}\text { Chip- } \\
\text { board }\end{array}$ & $\begin{array}{l}\text { Paper } \\
\text { or im- } \\
\text { itation } \\
\text { leather } \\
\text { over } \\
\text { chip- } \\
\text { board } \\
\text { and /or } \\
\text { veneer }\end{array}$ & $\begin{array}{l}\text { Fabric } \\
\text { over } \\
\text { chip- } \\
\text { board } \\
\text { and /or } \\
\text { veneer }\end{array}$ & $\begin{array}{l}\text { Leath- } \\
\text { er over } \\
\text { chip- } \\
\text { board } \\
\text { and /or } \\
\text { veneer }\end{array}$ & Fiber- & Metal & $\begin{array}{l}\text { Leath- } \\
\text { er }\end{array}$ & Other \\
\hline \multicolumn{9}{|c|}{ RAILROAD } \\
\hline $\begin{array}{l}\text { Suitcase } \\
\text { Overnight and }\end{array}$ & 8.8 & 9.4 & 39.0 & 11.9 & 9.4 & 6.3 & 11.3 & 3.9 \\
\hline $\begin{array}{l}\text { weekend } \\
\text { wardrobe.-. }\end{array}$ & $\begin{array}{l}4.8 \\
1.2\end{array}$ & $\begin{array}{r}11.4 \\
6.0\end{array}$ & $\begin{array}{l}60.6 \\
83.3\end{array}$ & $\begin{array}{r}10.8 \\
2.4\end{array}$ & 4.8 & $\begin{array}{r}1.7 \\
-\end{array}$ & $\begin{array}{l}5.0 \\
3.6\end{array}$ & $\begin{array}{r}.9 \\
3.5\end{array}$ \\
\hline \multicolumn{9}{|c|}{ BUS } \\
\hline $\begin{array}{l}\text { Suitcase } \\
\text { Overnight and }\end{array}$ & 5.1 & 25.6 & 46.2 & 2.6 & & 7.7 & 5.1 & 7.7 \\
\hline $\begin{array}{l}\text { weekend } \\
\text { wardrobe... }\end{array}$ & $\begin{array}{r}5.0 \\
10.0\end{array}$ & $\begin{array}{l}48.3 \\
10.0\end{array}$ & $\begin{array}{l}33.3 \\
40.0\end{array}$ & $\begin{array}{r}1.3 \\
20.0\end{array}$ & & $\begin{array}{r}5.0 \\
10.0\end{array}$ & $\mid-\cdots$ & $\begin{array}{r}7.1 \\
10.0\end{array}$ \\
\hline
\end{tabular}

mean specific reights (pounds per cubic foot) of luggage for different rolume ranges, as determined in 13 localities.

The ralues of the mean specific weights were used in calculating the loads to be used in specimens undergoing test in the laboratory.

The mean specific weights, for different volume ranges, are compared for rail and bus traffic in table 7 .

TABLE 6. Mean specific weight of luggage in different volume ranges

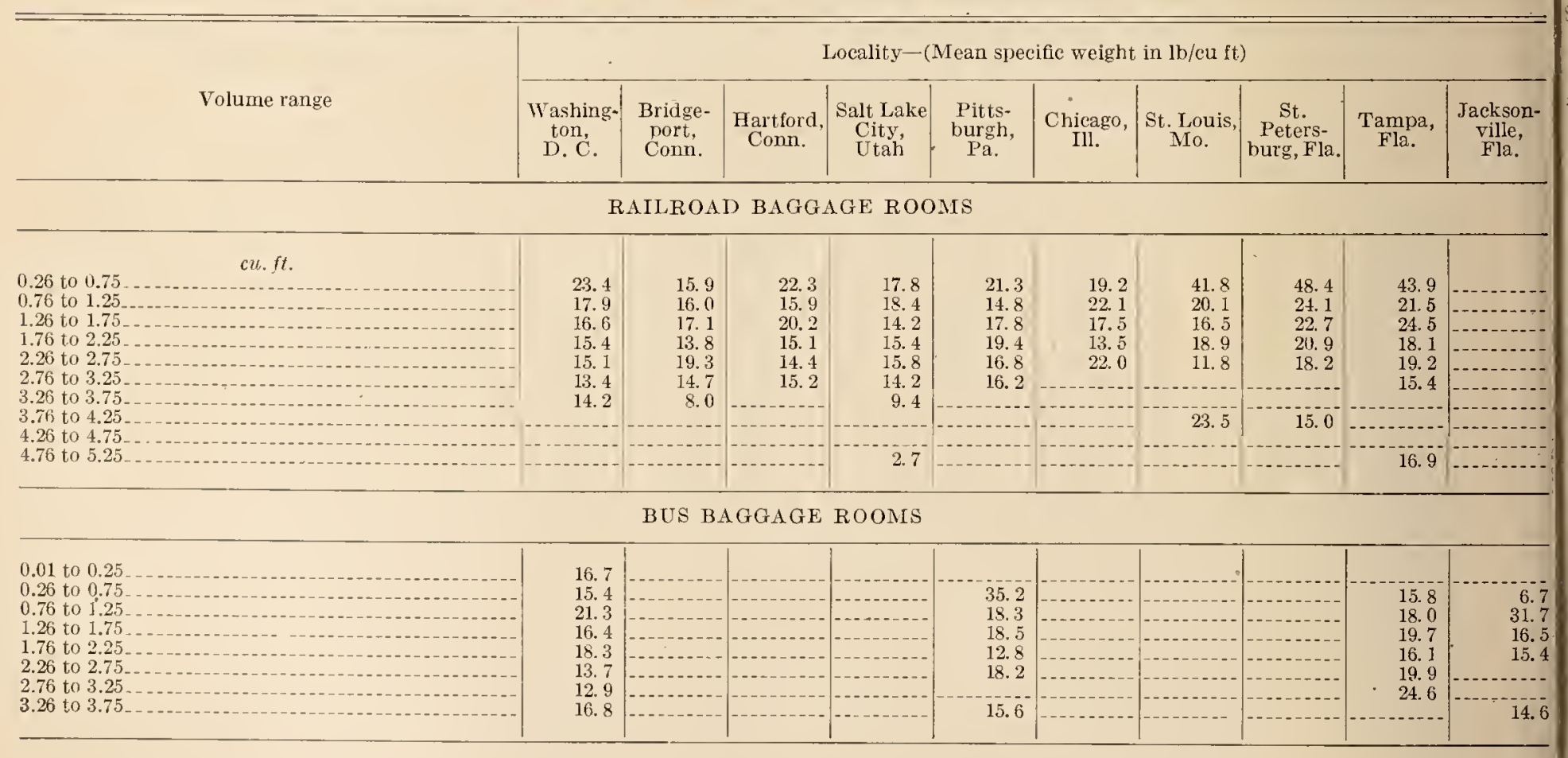


TABLE 7. Comparison of mean specific weight for different volume ranges

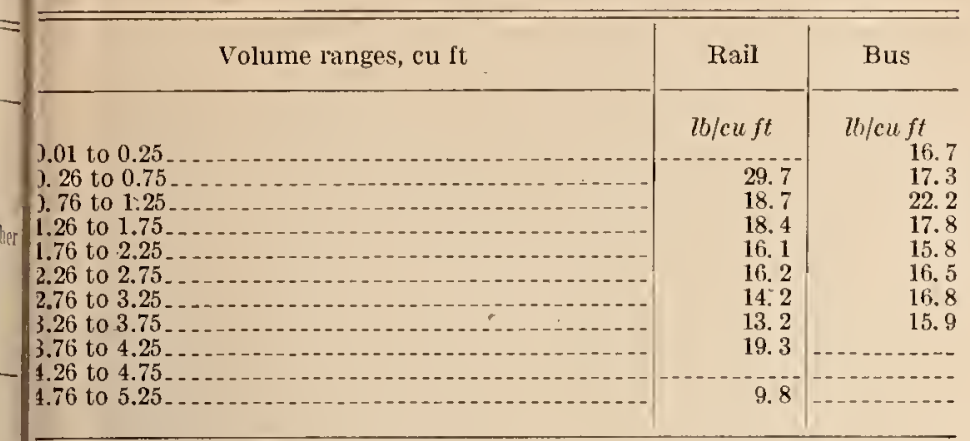

\section{Condition of Luggage in Service}

At the time that the cases were being examined for type, in both rail and bus terminals, appraisals of the items were made regarding their condition and appearance. Four grades of condition were used, approximately as follows:

Excellent: No damage other than soiling or abrasion which has not broken the surface

Good: Scuffs, scratches, dents or similar defects

Fair: Tears or breaks in outer covering, red rot in leather, but no puncture completely through walls; hardware damaged but still operable

Poor: Failure of hard ware, handle, frame, wall; or exposure of contents

Variations in the over-all condition of Juggage as found in stations in different localities are shown in table 8 .

TABLE 8. Condition of luggage in rail and bus stations

\begin{tabular}{|c|c|c|}
\hline Locality & $\begin{array}{l}\text { Excellent } \\
\text { and good }\end{array}$ & $\begin{array}{l}\text { Fair and } \\
\text { poor }\end{array}$ \\
\hline \multicolumn{3}{|l|}{ RAILROAD STATIONS } \\
\hline $\begin{array}{l}\text { Washington, D. C } \\
\text { Bridgeport, Conn- } \\
\text { Hartford, Conn } \\
\text { Salt Lake City, Utah } \\
\text { Pittsburgh, Pa. Pa. } \\
\text { Chicago, Ml } \\
\text { St. Louis, Mo } \\
\text { St. Petersburg, Fla } \\
\text { Tampa, Fla }\end{array}$ & $\begin{array}{r}\text { Percent } \\
57 \\
56 \\
58 \\
61 \\
60 \\
49 \\
42 \\
51 \\
60\end{array}$ & $\begin{array}{r}\text { Percent } \\
43 \\
44 \\
42 \\
39 \\
40 \\
51 \\
58 \\
49 \\
40\end{array}$ \\
\hline A veragc & 55 & 45 \\
\hline
\end{tabular}

BUS STATIONS

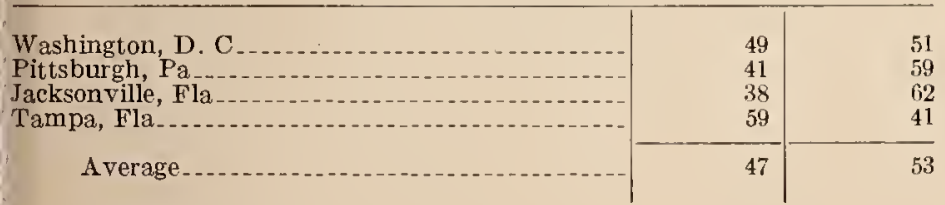

$830364-49-2$
In all but two railroad stations, the number of bags in excellent and good condition exceeds those in fair and poor condition. The opposite seems to be true for bus travel in three of four cities.

The comparison between railroad and bus baggage indicates that somewhat more cases of better quality are encountered in railroad baggage rooms than in bus baggage rooms.

\section{Types of Damage in Service}

A study of the types of damage occurring in service and the experience of baggage agents show that the majority of damages falls into these classes:

1. Broken or bent hardware (catches, locks, hinges).

2. Broken handles.

3. Separation of frames, or of covering from frame.

4. Punctures of surfaces (sides, ends, bottom, top).

5. Scuffing and tearing of covering or binding.

6. Damage by water, grease, oil, etc.

The last item rarely leads to damage of the contents, or to permanent impairnent of the functional operation of the bag, althongh objectionable discoloration may result. Scuffing or tearing of the covering, although disfiguring, does not usually expose the contents of the bag or damage it to such an extent as to render it useless. The first four items are considered to be the most serious causes for damage and loss of linggage and contents, and attention was concentrated on them in laboratory stuclies.

Typical examples of damage occur'ing in actual service are illustrated in figrues 1, 2, and 3.

Types of damage to hardware are pictured in figure 2.

Four of the ways in which a handle may fail are shown in figure 3.

The loss of a handle in service is serions not only from the standpoint of inconvenience to all who must carry the bag, but also because its detachment may cause the whole case to be lost, as identification tags or checks are usually attached to the handle. Loss of the handle or failnue of a conponent part sometimes results in serious damage to the case itself by causing a fall from a considerable height onto a hard surface, as when the failure occurs because the handle is being used to pull the bag from a rack.

Some serious failures are caused by external loads, from other luggage stacked on a bag, or similar conditions. Luggage may be stacked to a height of several feet as a space-conserving measure. There is sometimes a tendency to force 
a small bag into insufficient residual space in a packed compartment, with the result that a compressive for'ce is exerted on all bags in the compartment. A much more prevalent practice is

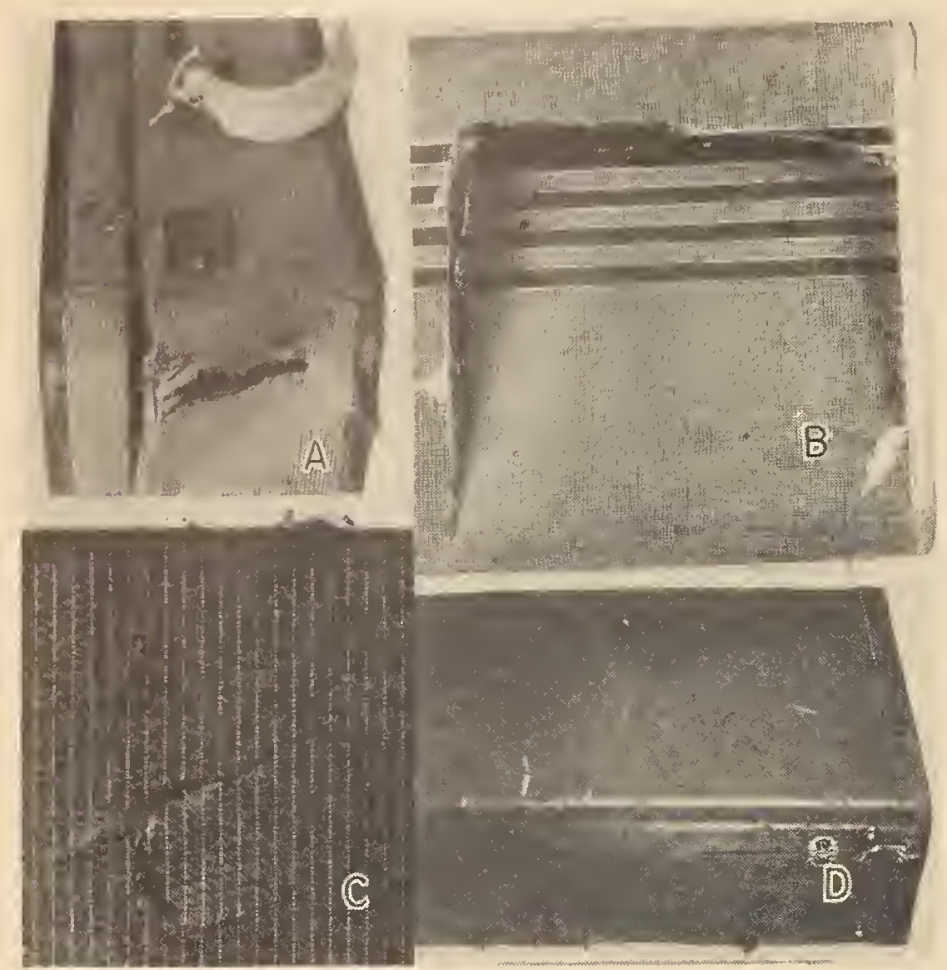

FIgURe 1. Types of damage to luggage in actual serviee. $A$, Broken frame; $B$, rectangular fracture of plywood; $C$,
puncture of surface; $D$, scuffing of leather.

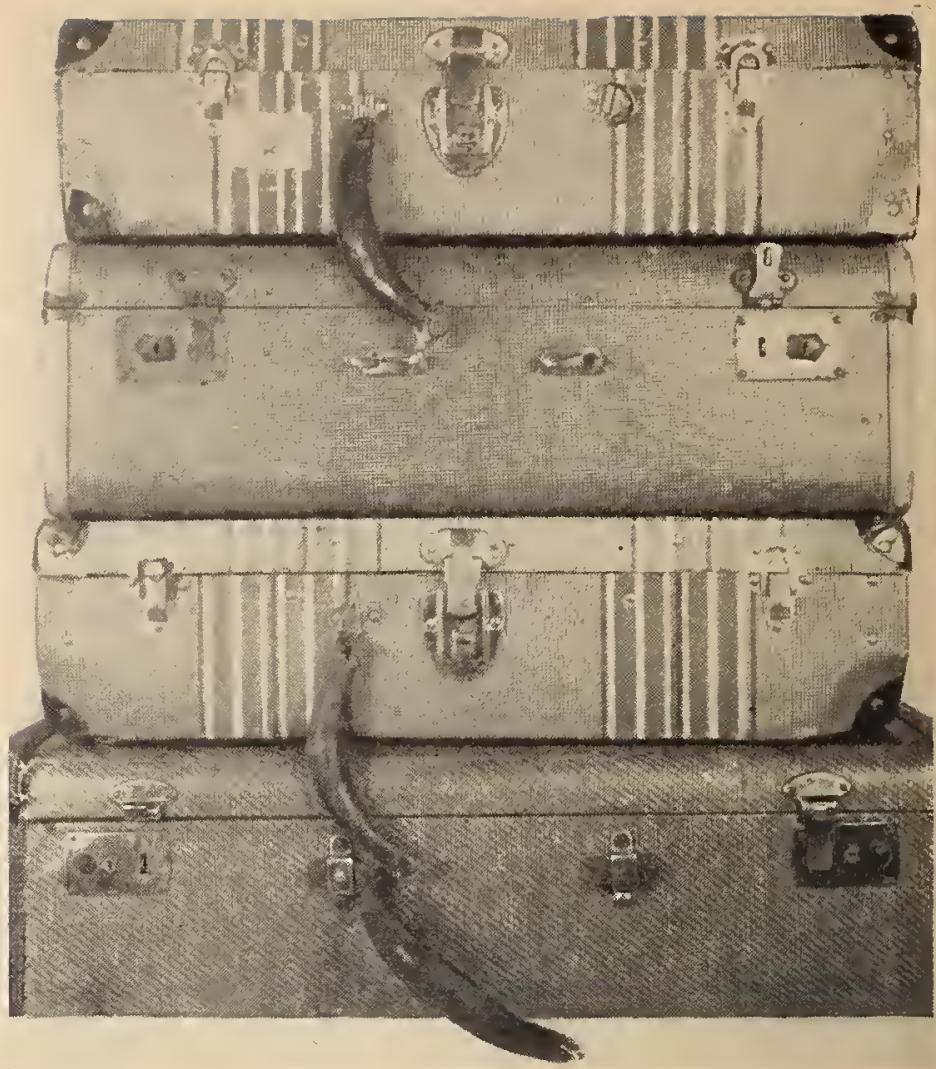

Figure 3. 'Types of lamage to luggage handles in service.

Top, handle broken away from D-ring, and metal reinforcement in handle pulled out; second, handle disappeared in service ; third, rivets fastening handle plate to bag pulled through top of bag; bottom, leather landle broke across slot through which passed metal pin fastening it to bag.

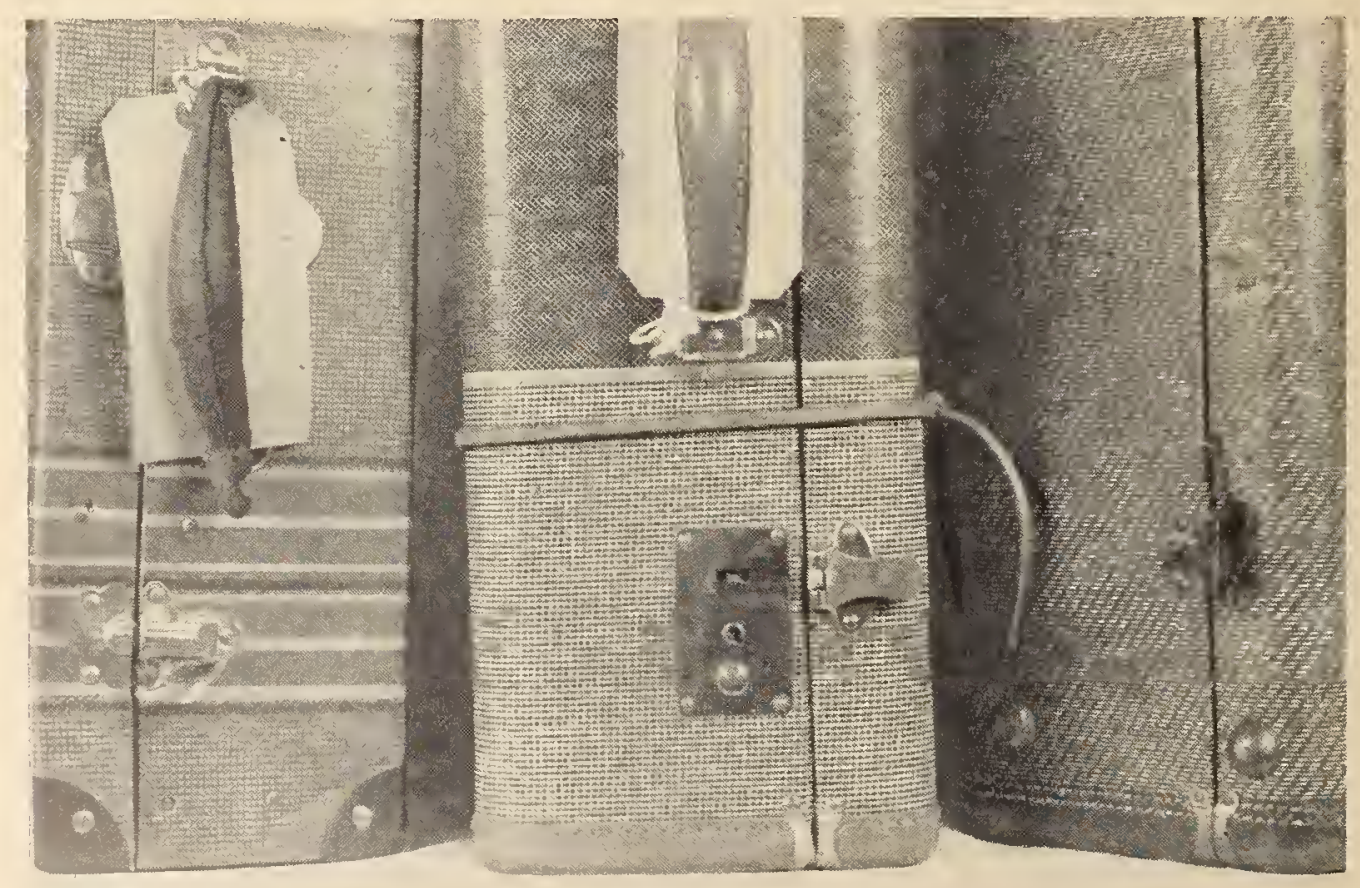

Figure 2. Types of damage to luggage hardware in service.

Right, hinge failure caused by rirets pulling out; center, hasp of internal-type catch broken at spot-welds; left, morable piece of external-type catch bent and pulled out at one side.

that travelers often use luggage for other than its intended purposes, such as a seat or a stepladder to gain access to overhead baggage racks. It is estimated that static external loads of 100 to 200 pounds are quite frequent, and that loads up to 400 pounds may occasionally be found. 
Bags may drop from various heights in service because of handle breaks, methods of handling and stacking, and other reasons. Luggage has been seen to fall from a height of 6 feet after being carelessly stacked on older style trucks. Occasionally the failure of a handle may lead to dropping a bag on a station floor; sometimes the bag then opens and scatters the contents. One type of impact peculiar to air lines is that caused by the sudden rise or fall of the plane in turbulent air.
In extreme conditions a force of two to three times gravity may be imposed.

The surfaces of bags are sometimes fractured in service, either by falling on sharp objects, or by sustaining a blow from a falling object, such as the corner of another bag. Damage is apt to be more severe for a rigid type of container, such as fiberboard or veneer construction, particularly when the surface is not supported by full packing within the bag.

\section{Description of Luggage Used in Experiments}

\section{Types and Sizes}

In order to obtain information on the effect of types of materials, sizes, etc., to the maximum extent consistent with practical limitations on the number of bags to be studied, luggage for test was purchased according to the following scheme. (The figures in parentheses give the approximate retail price, with tax, in June 1947.)

Bags about 21 inches long:

1. Chipboard $(\$ 2.50)$.

2. Vulcanized fiberboard (\$6).

3. Fabric cover:

a. Lower-priced $(\$ 12)$.

b. Higher-priced $(\$ 18)$.

4. Plastic cover $(\$ 20)$.

5 . Leather cover $(\$ 36)$.

Bags about 26 inches long:

1. Chipboard $(\$ 3.50)$.

2. Vulcanized fiberboard $(\$ 12)$.
3. Fabric cover:

a. Lower-priced $(\$ 17)$.

b. Higher-priced $(\$ 27)$.

4. Plastic cover $(\$ 33)$.

5 . Leather cover $(\$ 51)$.

The two sizes, 21 inches and 26 inches, were selected because these represent the most popular sizes used, according to surveys. The smaller size lepresents approximately week-end, overnight, and other small cases; the larger size is similar to wardrobe, pullman, fortnighter cases, and the like. Three identical specimeus of each group were purchased in the open market; two were tested in the laboratory; and the third was subjected to an actual service test.

\section{Chipboard Cases}

The unused chipboard cases are shown in figures 4, A, and 5, A. The smaller bag was 23 inches
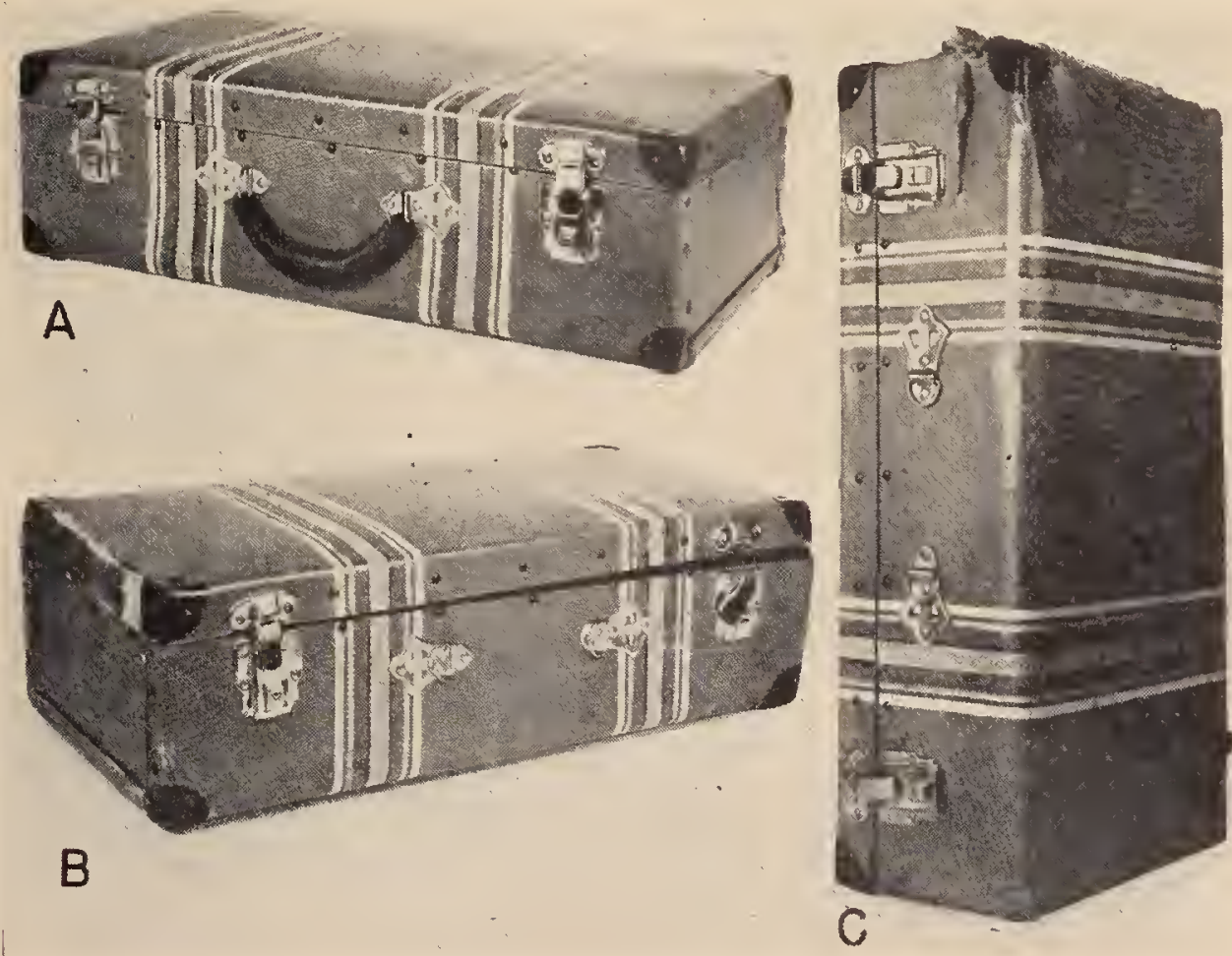

Figure 4. Small chipboard case.

$A$, Unused; $B$, after laboratory tests ; $C$, after service test. 

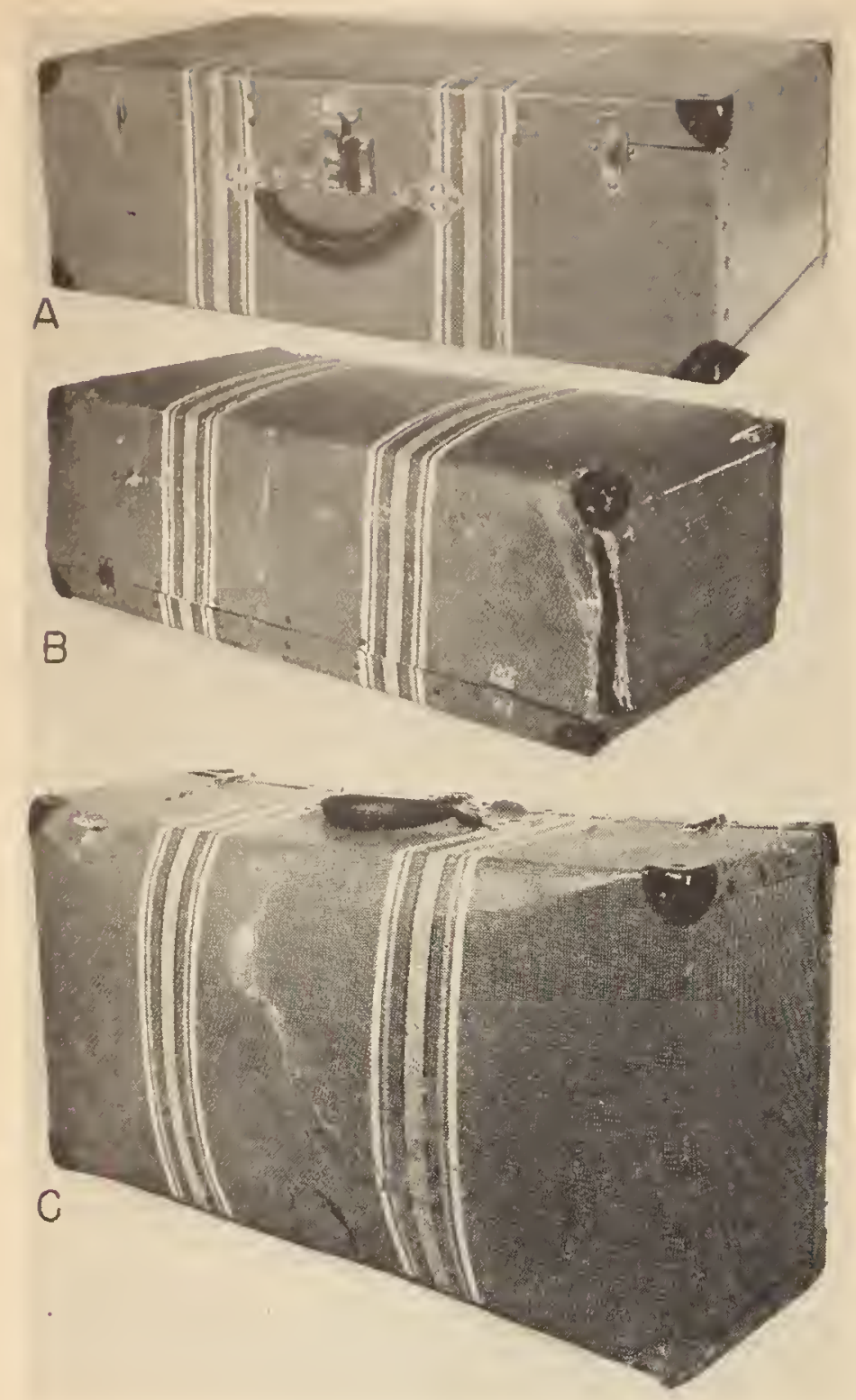

\section{Vulcanized Fiberboard Cases}

Photographs of the mused vulcanized fiberboard cases are shown in figures $6, \mathrm{~A}$, and $7, \mathrm{~A}$. The retail prices of these cases were approximately $\$ 6.00$ and $\$ 12.00$ for the smaller and larger sizes, respectively. These cases were made almost entirely of thick vulcanized fiberboard, treated with a coating that seemed to be an alkyd resin. They had black metal bindings, and the surfaces were fastened at the edges with a large number of black metal rivets. There was no reinforcing frame. The hardware was moderately heavy.

The handles were formed of leather over paper composition, reinforced by a metal wire or rod about $1 / 8$ inch in diameter, which passed through steel buttons at each bend, and was flattened at the end to prevent the buttons from becoming detached. The ends of the handle passed under sheet metal strips, about $1 / 2$ inch wide, which were riveted to the body of the case, the rivets passing through a sheet of reinforcing material of the same composition as the body of the case.

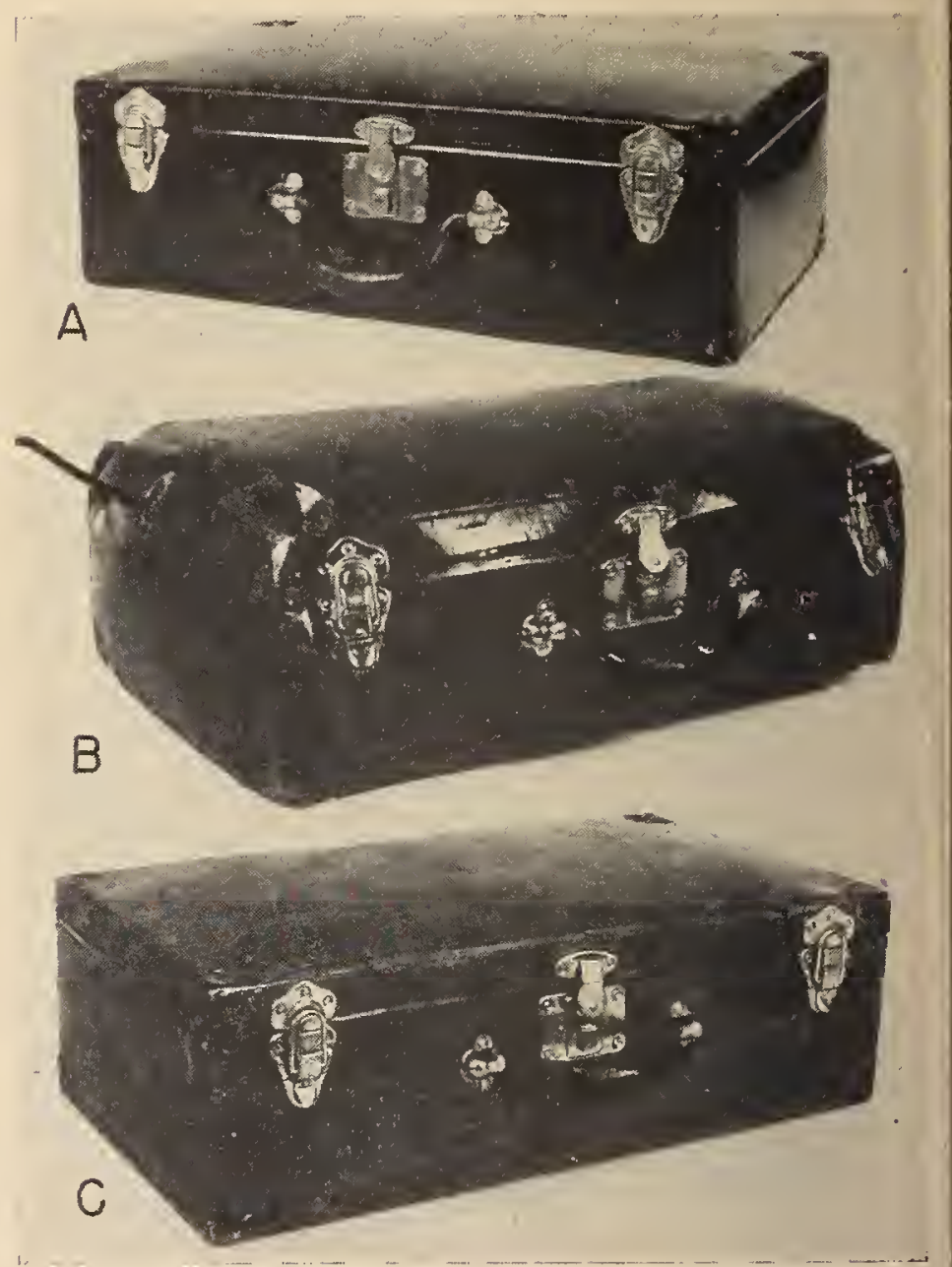

Figure 6. Small vulcanized fiberboard case.

$A$. T'nused ; $B$, after laboratory tests; $C$, after service test. 


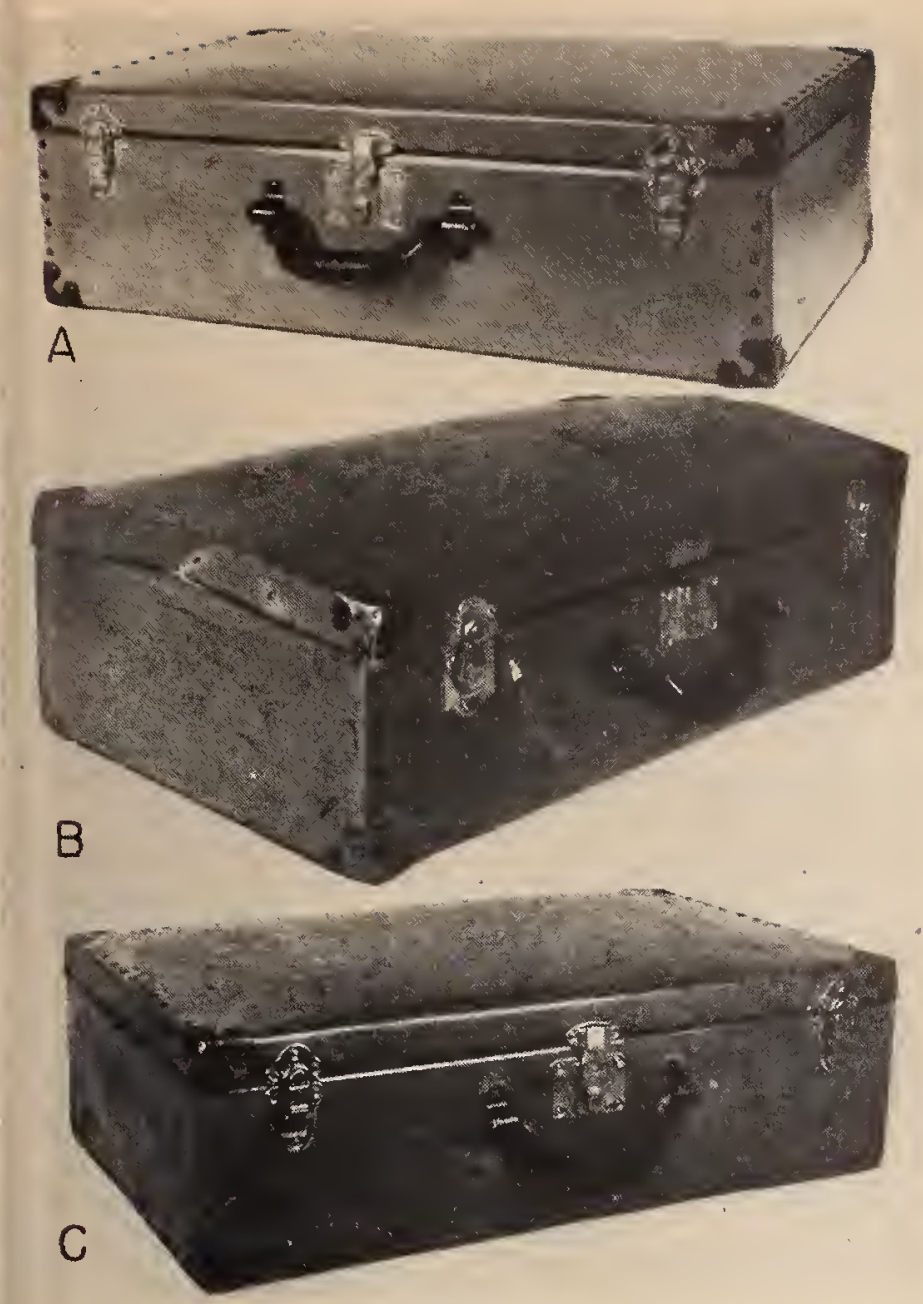

Figure 7. Large vulcanized fiberboard case. $A$, Unised ; $B$, after laboratory tests ; $C$, after service test.

\section{Lower-Priced Fabric-Covered Cases}

The unused lower-priced fabric-covered cases are shown in figures $8, \mathbf{A}$, and $9, \mathbf{A}$. The retail prices were about $\$ 12.00$ for the 21 -inch and $\$ 17.00$ for the 26-inch size. They had certain components reputed to cause trouble in service, namely, chipboard sides under the fabric, spot-welded hasps on the internal-type catches, and hardware generally of light weight.

The handles were composed of a double thickness of heavy impregnated fabric, sewn together at the edges, and looped at the ends over two 1-inch D-rings. The D-rings passed under metal handle plates, which were fastened to the body of the bag by bent extensions of the plates themselves.

\section{Higher-Priced Fabric-Covered Cases}

The unused higher-priced fabric-covered cases, retailing at about $\$ 18.00$ and $\$ 27.00$ for the smaller and larger sizes, respectively, are shown in figures $10, A$, and $11, A$. The most obvious differences from the less expensive fabric-covered cases were that the fabric was more closely woven, that the bodies of the cases were wood veneer instead of chipboard, and that the hardware was all brass and of heavier weight. The hasps on the catches were not simply spot-welded, but extended through two small holes in the hinged metal part of the catch.

The handles were of the post type, and were made of leather orer paper composition. Through

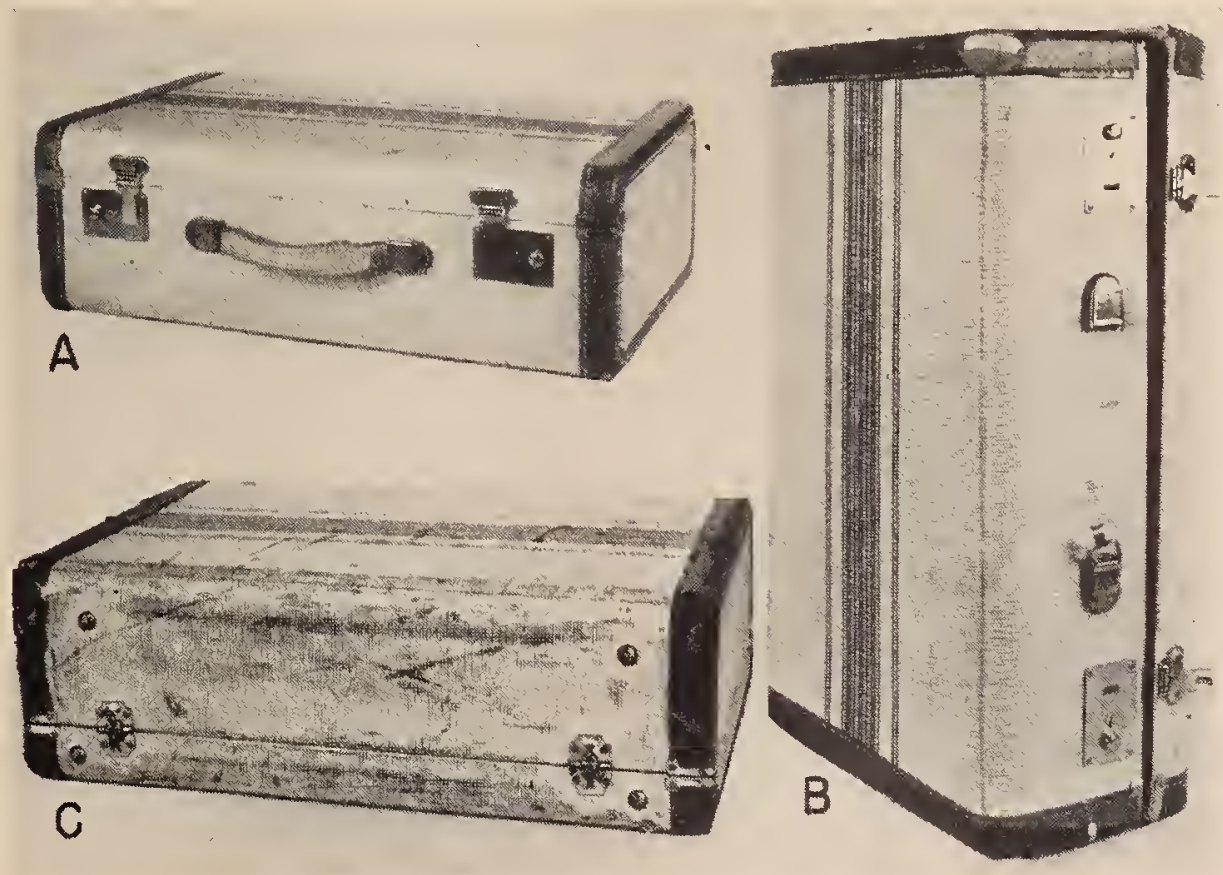

Figure 8. Lower-priced small fabric-covered case.

$A$, Unused; $B$, after laboratory tests ; $C$, after service test. 


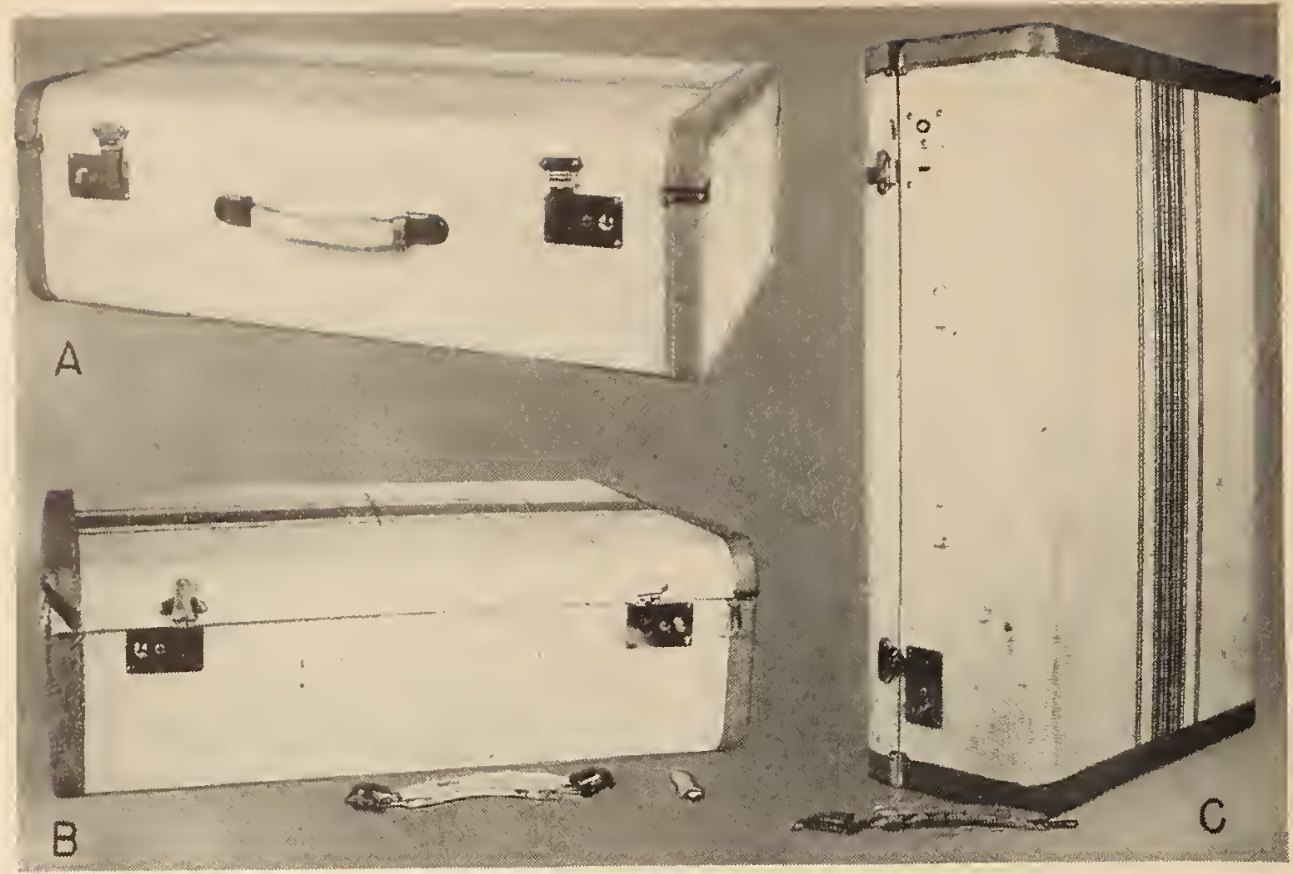

Figure 9. Lower-priced large fabric-covered casc.

$A$, Unused; $B$, after laboratory tests ; $C$, after service test.

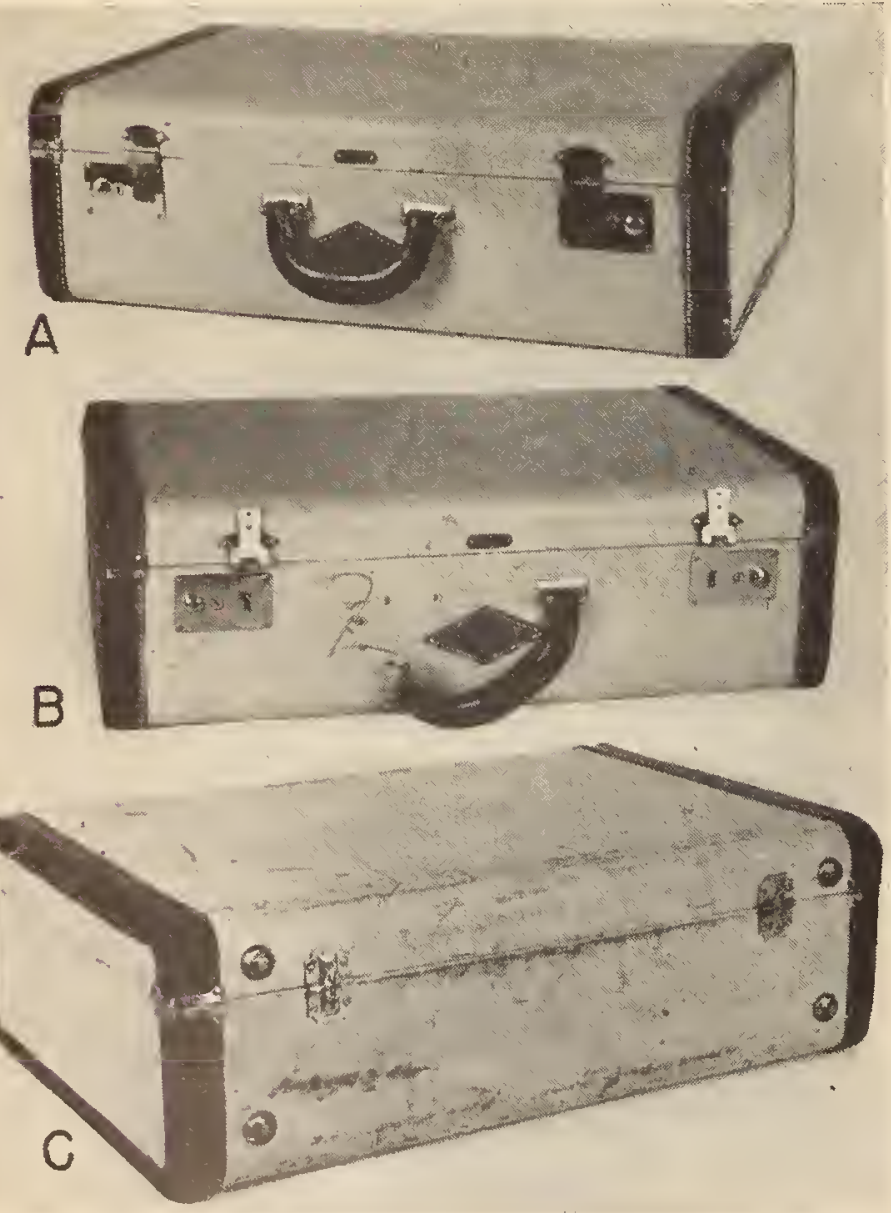

Figuke 10. Higher-priced small fabric-covered case. $A$, Unused ; $B$, after laboratory tests ; $C$, after service test.

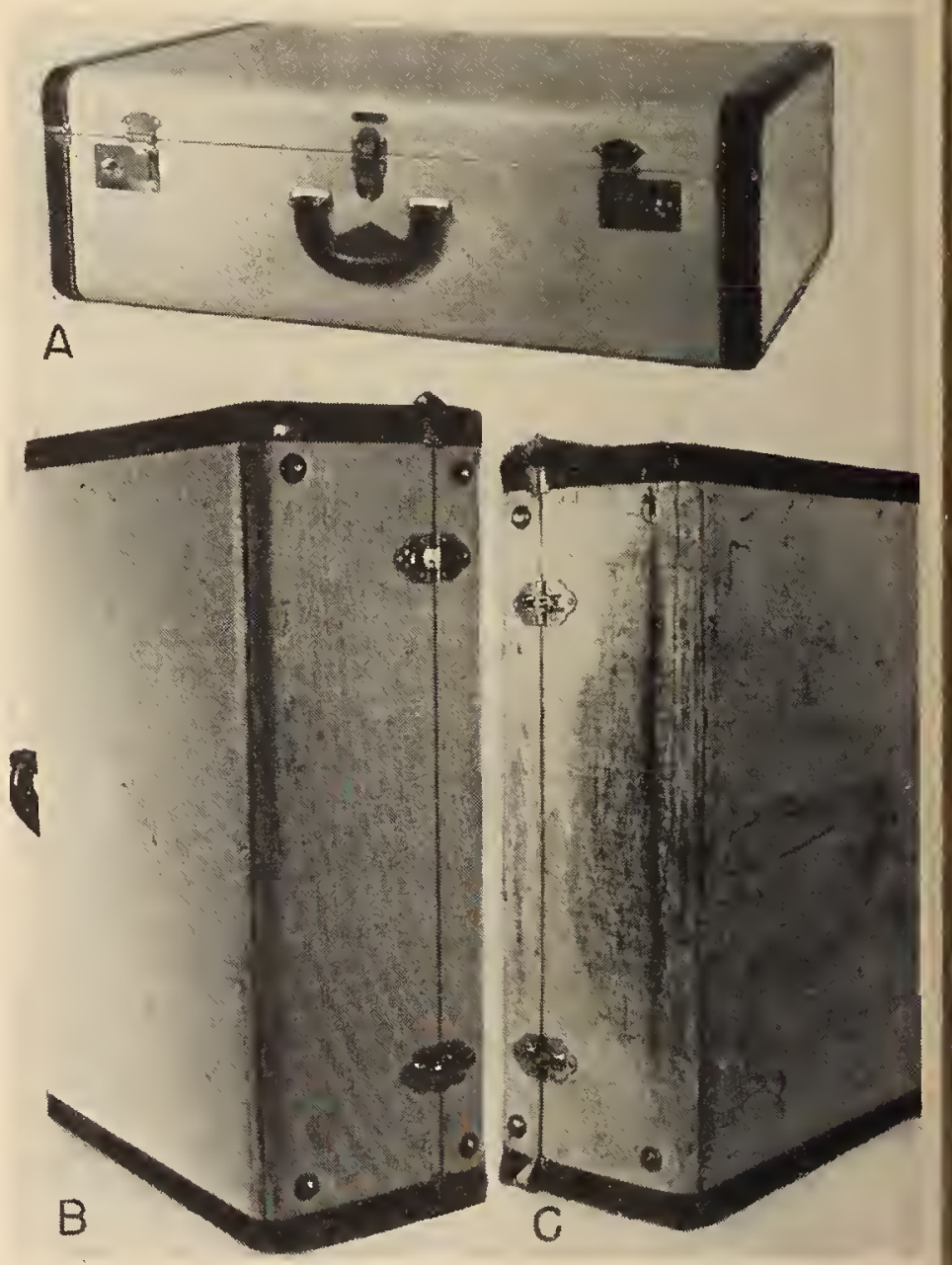

Figule 11. Higher-priced large fabric-covered case. $A$, Unused ; $B$, after laboratory tests ; $C$, after service test. 
the ends of the handles passed a brass pin, the ends of which were held by hollow metal posts, projecting from a brass plate fixed to the bag by bent metal strips that passed through the body of the bag and then bent at right angles.

\section{Plastic-Covered Cases}

The plastic-covered cases were made of wood veneer to which was bonded a surface coating of a cellulosic plastic, probably cellulose nitrate. The unused bags are shown in figures $12, \mathrm{~A}$, and $13, A$. This material has become increasingly popular in recent year's, and among baggagemen it has a good reputation for durability. It has a glossy brown finish, with an embossed pattern somewhat resembling alligator leather. The larger case was bound with metal, liberally riveted, and the smaller with leather. The hardware on both bags was quite heavy, the catches being of a modified external tension type. Retail prices,
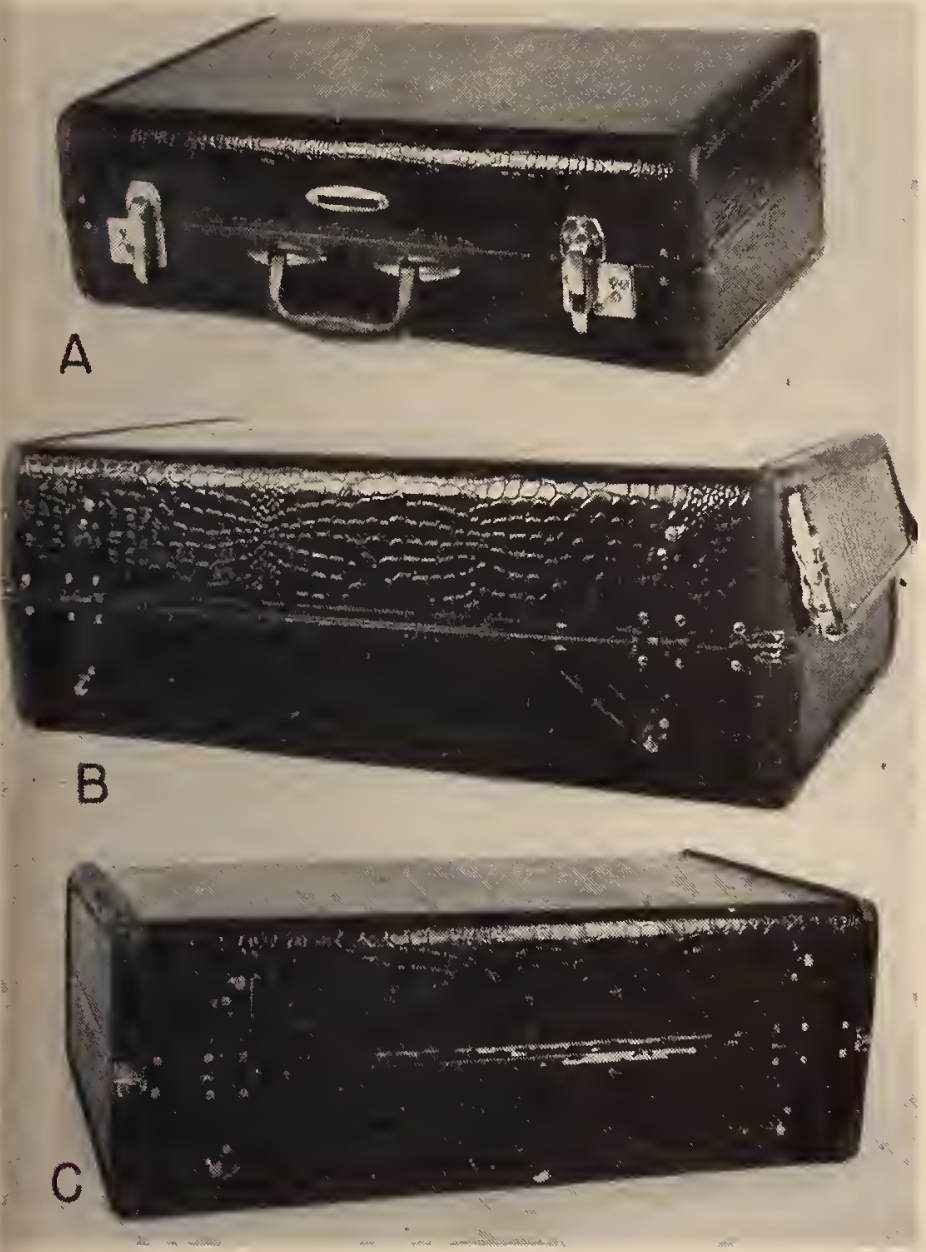

FIGURE 12. Small plastic-covcred case.

$A$, Unused; $B$, after laboratory tests ; $C$, after service tests.
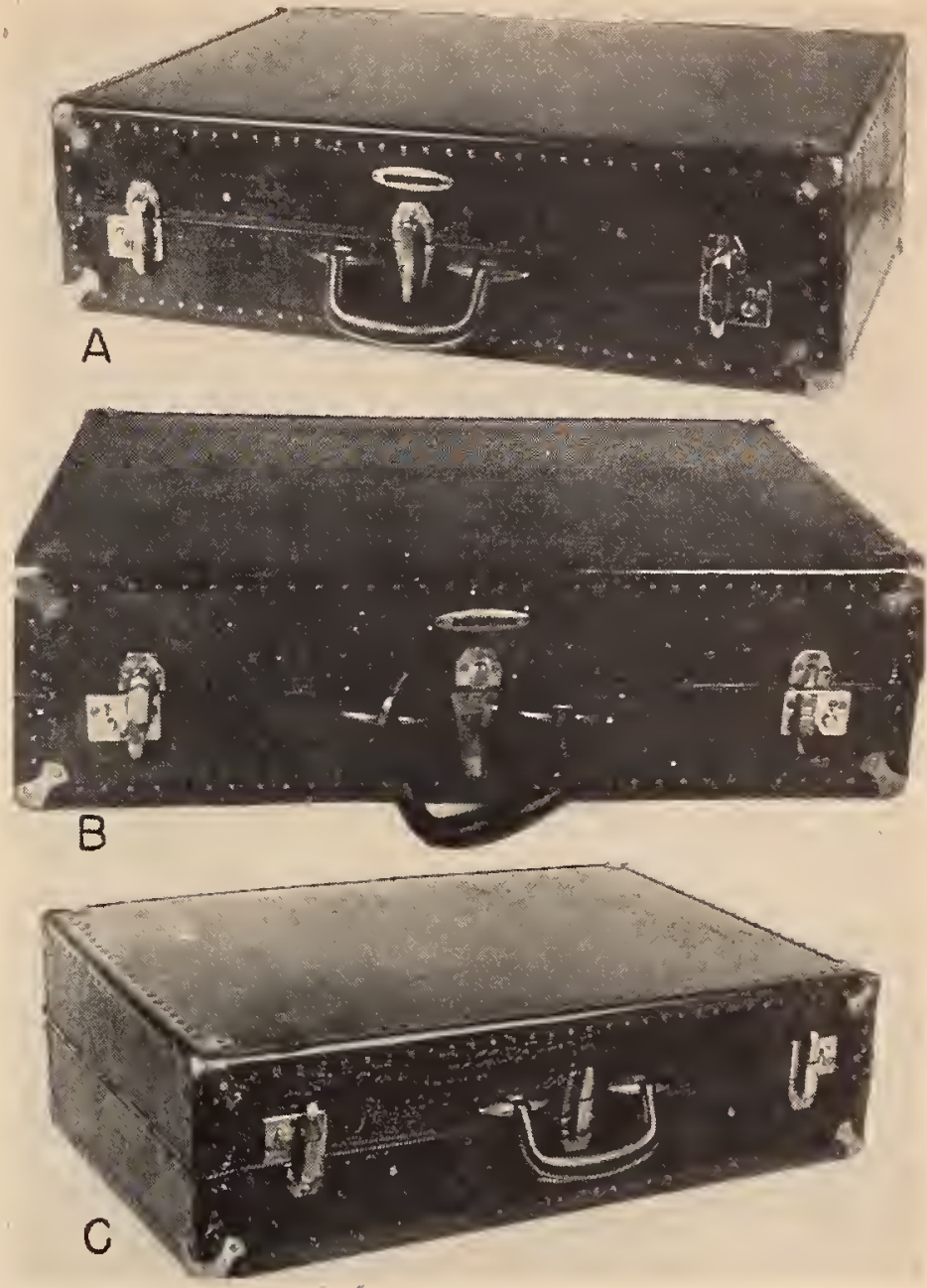

Figure 13. Large plastic-covercd case.

$A$, Unused ; $B$, after laboratory tests ; $C$, after service tests.

about $\$ 20.00$ for the smaller and $\$ 33.00$ for the larger bag, seemed to be quite miniform at different dealers. The handle was made of rubber, molded over a metal strip which passed around a pin fastened to a brass plate, in turn fastened to the case with bifurcated rivets. This fastening assembly was covered with a brass housing, presumably to protect it from impacts.

\section{Leather-Covered Cases}

The unused leather-covered cases are shown in figures $14, \mathrm{~A}$, and $15, \mathrm{~A}$. They cost about $\$ 36.00$ and $\$ 51.00$ for the 21 -inch and 26 -inch bags, respectively. They had wood veneer bodies, covered and bound with grain leather splits. 'Their' hardware was all brass, of a moderately lieavy grade; the hardware and handles were similar to those of the higher-priced fabric-covered cases. 


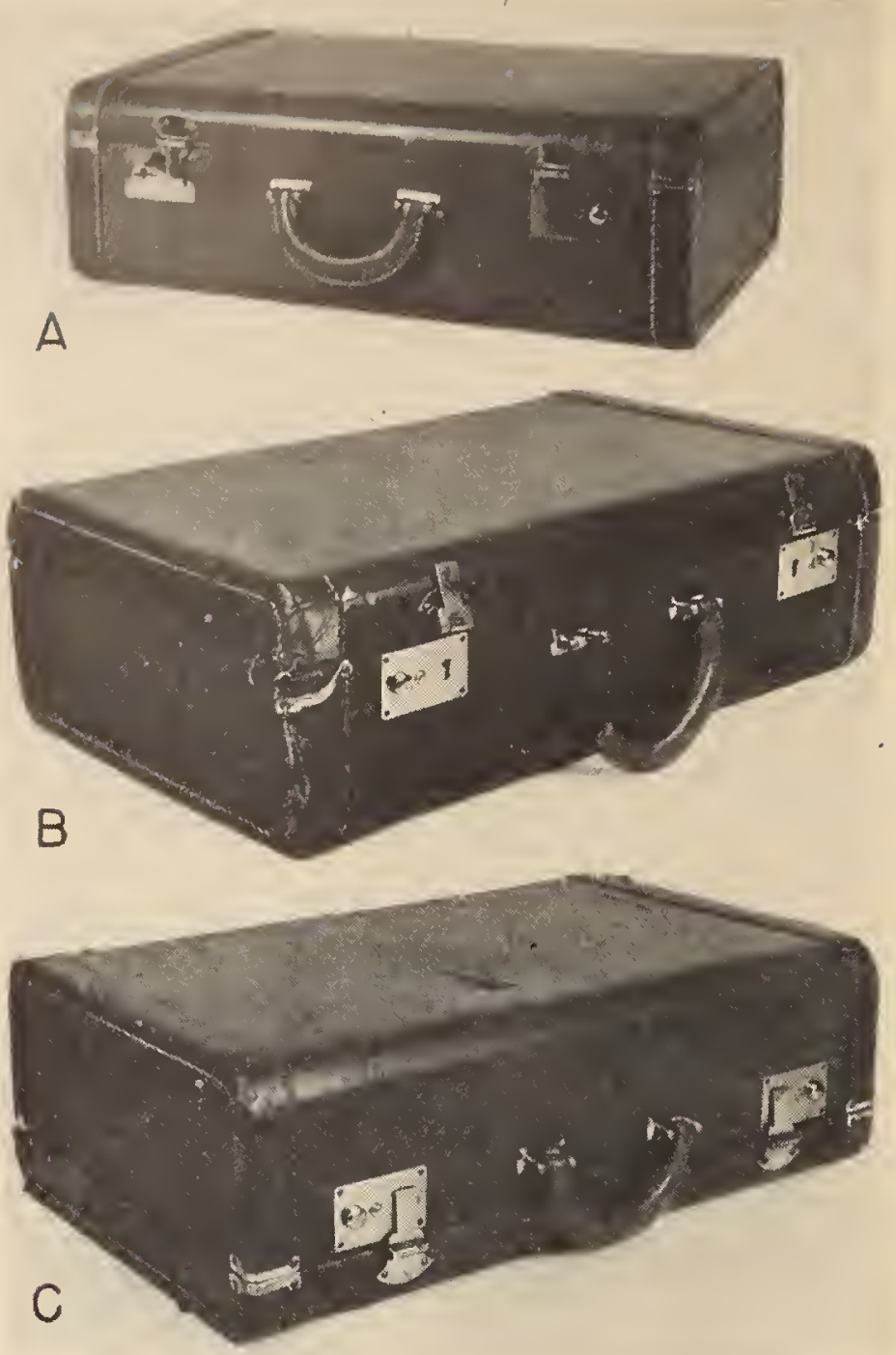

Figure 14. Small leather-eovered case.

$A$, Unused ; $B$, after laboratory tests ; $C$, after service tests.
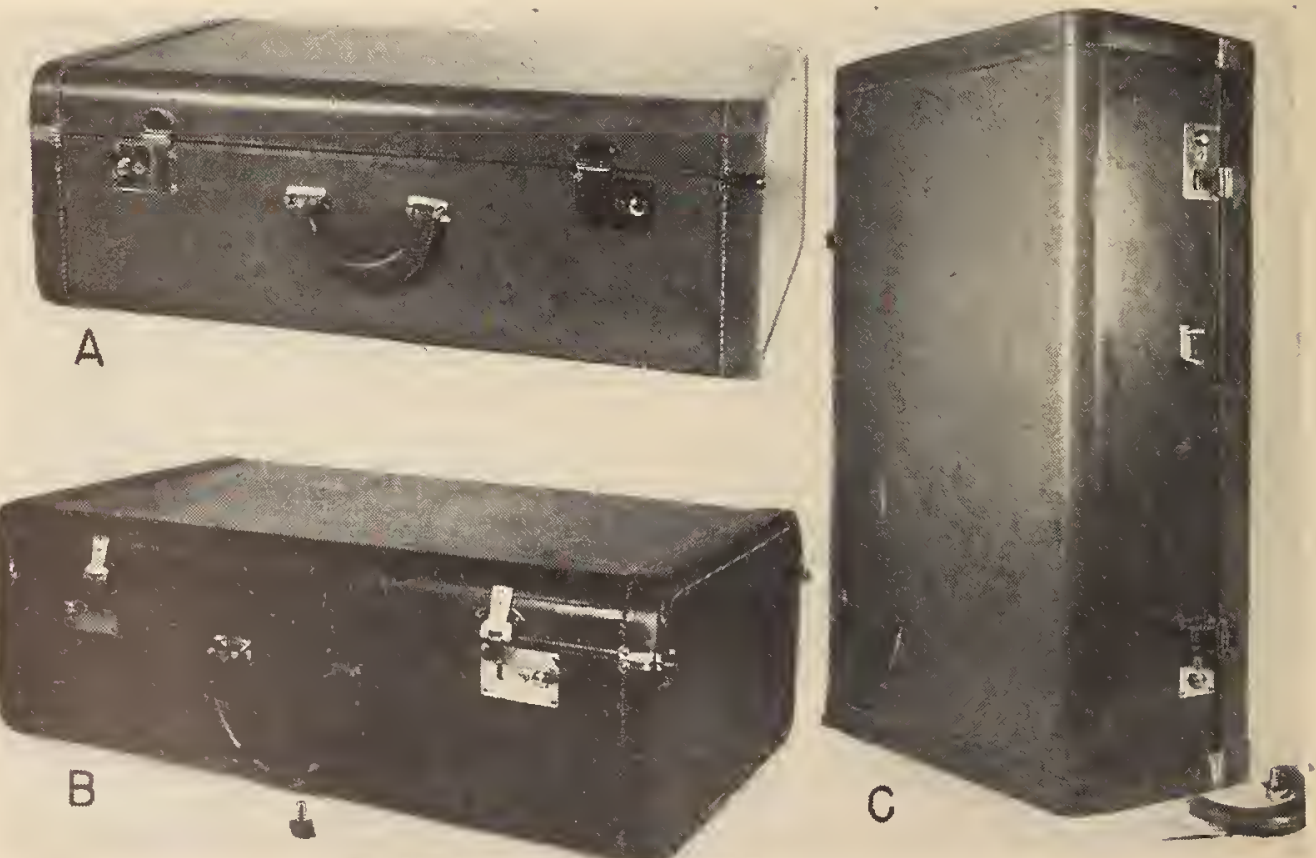

FigURE 15. Larae leather-eovered ease.

$A$, Unused; $B$, after laboratory tests; $C$, after service tests. 


\section{Laboratory Tests}

\section{Description of Test Methods}

Five physical tests were used for the qualitative and quantitative reproduction, in the laboratory, of the damage occurring in service. These are designated the handle fatigue test, the static load test, the divided-table drop test, the puncture test, and the revolving drum test. The static load test is made with the bag empty, since in this condition it does not offer the added resistance afforded by tight packing. The puncture test is made on segments cut from the walls of the bag. The other three tests are made on loaded bags, since this condition reproduces the more severe conditions to be expected in service. The loads used (including the weights of the bags themselves) were calculated from the results of the surveys. For each volume range, the mean specific weight plus three times its standard deviation was taken and the result multiplied by the midpoint of the range. This figure, called the "maximum expected load," represents a weight that would not be expected to be exceeded more than three times in a thousand in actual service. The maximum expected loads are shown in table 9.

TABLE 9.-Maximum expected loads (suggested for laboratory tests of loaded luggage)

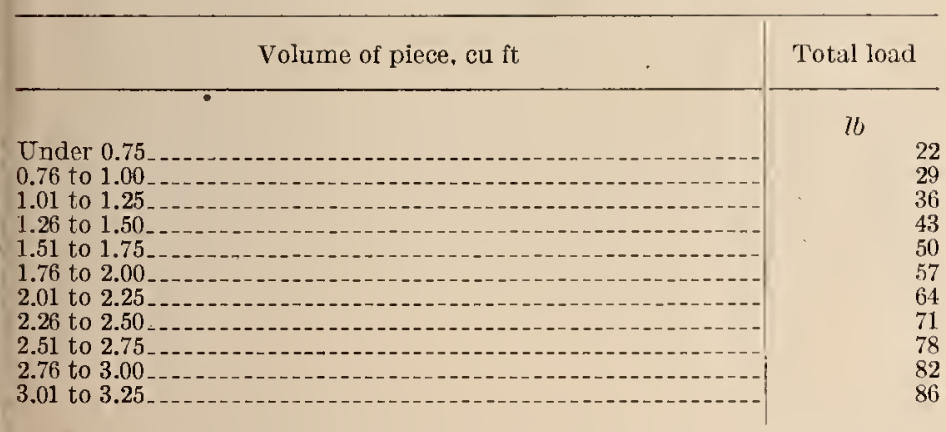

The bags were loaded as much as possible with clean, household rags, with from three to six common bricks, depending on the size of the bags. The bricks were covered with cloth and located centrally in the bags so that they could not shift in "position when the bags were tested.

In describing damage and other characteristics of the bags in the laboratory, it is convenient to identify the faces, edges, and corners of a bag by a numerical system. The ASTM method for shipping containers was used. In applying this method, the bag is laid on its side, the liandle toward the observer and the lid at the top, in the position customarily used for opening or packing. The lid is designated as face number 1 ; the handle face, number 2 ; the face opposite the lid, number 3 ; and the bottom or hinge face, number 4 . The end at the observer"s left is number 5 and the one at his right, number 6 . The edges are identified by the numbers of the two faces that intersect to form that edge; for example, 1-2 identifies the edge where the lid and handle side meet. The corner's are identified by the numbers of the three faces that meet to form that corner. For example, 1-2-5 identifies the corner where the lid, the handle side, and the left end meet. This system was used throughout the tests to record the location of damage. It is applicable, in modified form, to pieces of luggage that are not essentially rectangular parallelepipeds, such as Boston bags and hat boxes.

\section{(a) Handle Fatigue Tests}

The apparatus designed for the handle fatigue test is shown in figure 16. It picks bags up and sets them down repeatedly in a manner simulating the action of a person picking up a bag by hand and setting it down. The device operates at the rate of 37.5 pickups per minute, and exerts a peak force of approximately 1.8 times gravity, as measured against a 50-pound weight. It is

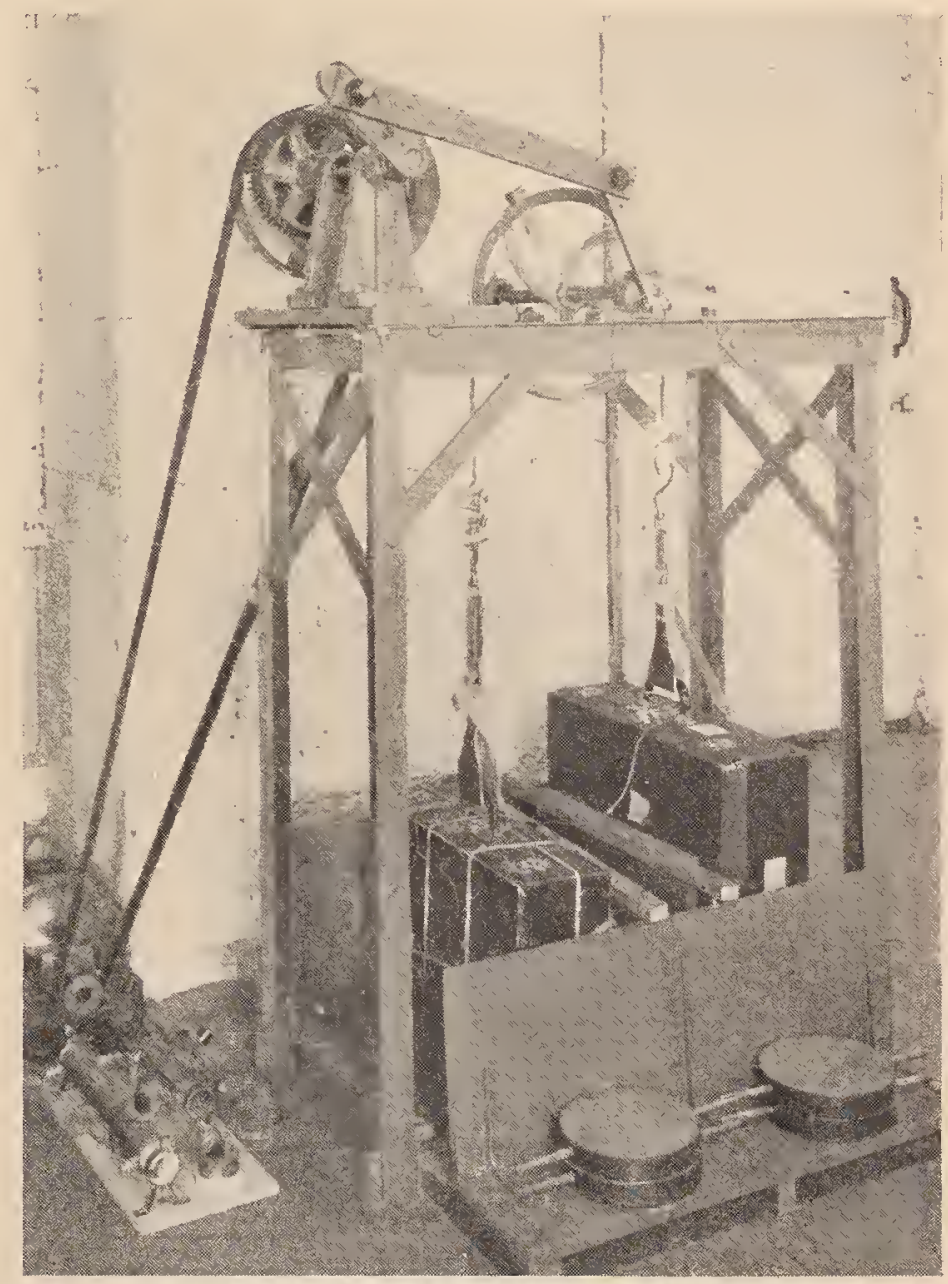

Figure 16. Handle fatigue test apparatus. 
equipped with an electrical relay system that stops the operation as soon as a handle fails, and an antomatic counter that records the number of pickups. Intended primarily to evaluate the durability of handles, the machine also stresses the hardware and the frames. The results of this test appear to approximate closely the behavior of handles in actual service, even though in service they may be exposed to other types of forces.

\section{(b) Static Load Tests}

For the static load test, a weight of 150 pounds, occupying an area 5 by 8 inches, was placed successively on the center of a side, end, and top of an empty, closed bag, and allowed to remain in each position for 5 minutes. Permanent deformation, breakage, or tearing indicated failure of the specimen. Permanent creasing of the covering material, although disfiguring, was not considered a failure.

\section{(c) Divided-Table Drop Test}

This test is made by means of a device that permits the loaded bag to be dropped on any edge, surface, or corner. The apparatus is illustrated in figure 17 and meets the requirements of the ASTMI Designation D775-45T.

The procedure consisted in dropping the loaded bag successively on each of the surfaces, edges, and corner's from lieights of $11 / 2,2,21 / 2,3,31 / 2,4,41 / 2$. and 5 feet. Thus 26 falls were made at each of the indicated heights, or until failure occurred. After each fall, the specimens were examined and damages were described and recorded.

In order to provide a quantitative measure of the performance of the bags, an arbitrary system for assigning scores for each fall was developed. Each bag, before starting the test, was given a rating of 1.11. As long as no damage was sustained, the bag was given a score of 1.11 for each fall. When the bag received some injury, a value commensurate with the severity of the damage was subtracted from the starting score. The bag was then assigned this new score for each subsequent drop until further damage occurred, when an additional deduction, again proportional to the severity of the damage, was made. This procedure was continued to the end of the test. The total score for any bag was the summation of its scores for the individual falls. Failure of the bag, or the reduction of the score to zero, at any drop, resulted in the summation of the scores up to that point. Thus, a bag failing at a low elevation (early in the test) would have a low total score. A bag withstanding drops from all eight heights, but suffering considerable damage at the lower heights, would have a lower score than one that also dropped from the eight positions but was

${ }^{3}$ ASTI Methods of Standards part III, B, p. 1266 (1946).

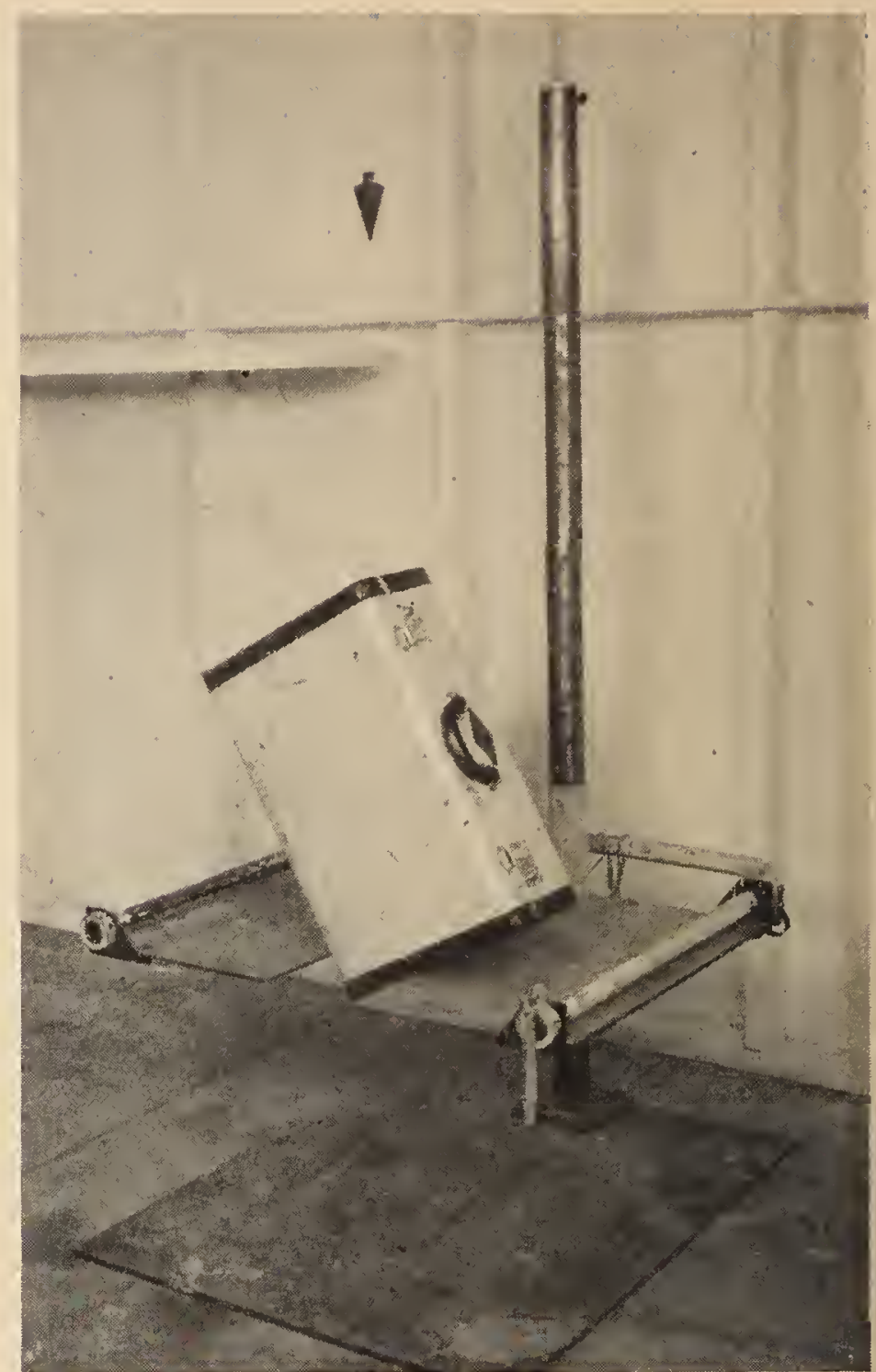

FiguRe 17. Divided-table drop test apparatus.

damaged at the higher levels. Hence, the system gives due credit to a bag for its ability to withstand punishment as the test progresses. A bag showing no damage at all would lave been dropped 208 times, and have a total score of 230.81 .

The reductions in score were made in accordance with an arbitrary schedule. The penalties ranged from 0.01 to 0.50 , depending upon the seriousness of the dama ge and the probable effect on the future performance of the bag. The complete system for score reductions is shown in table 10 .

Where a range is shown, the value selected depends on the severity of the damage. Three observer's independently assigned and calculated scores for all the test specimens and obtained good a greement for the total numerical scores of each bag, the root-mean-square variation averaging less than 4 percent.

Bags were classified as failures because of handles completely pulled or broken loose, broken frames, all latches broken or inoperative, or large tears in the surface. With the exception of dam- 
TABLE 10. Score reductions for drop test.

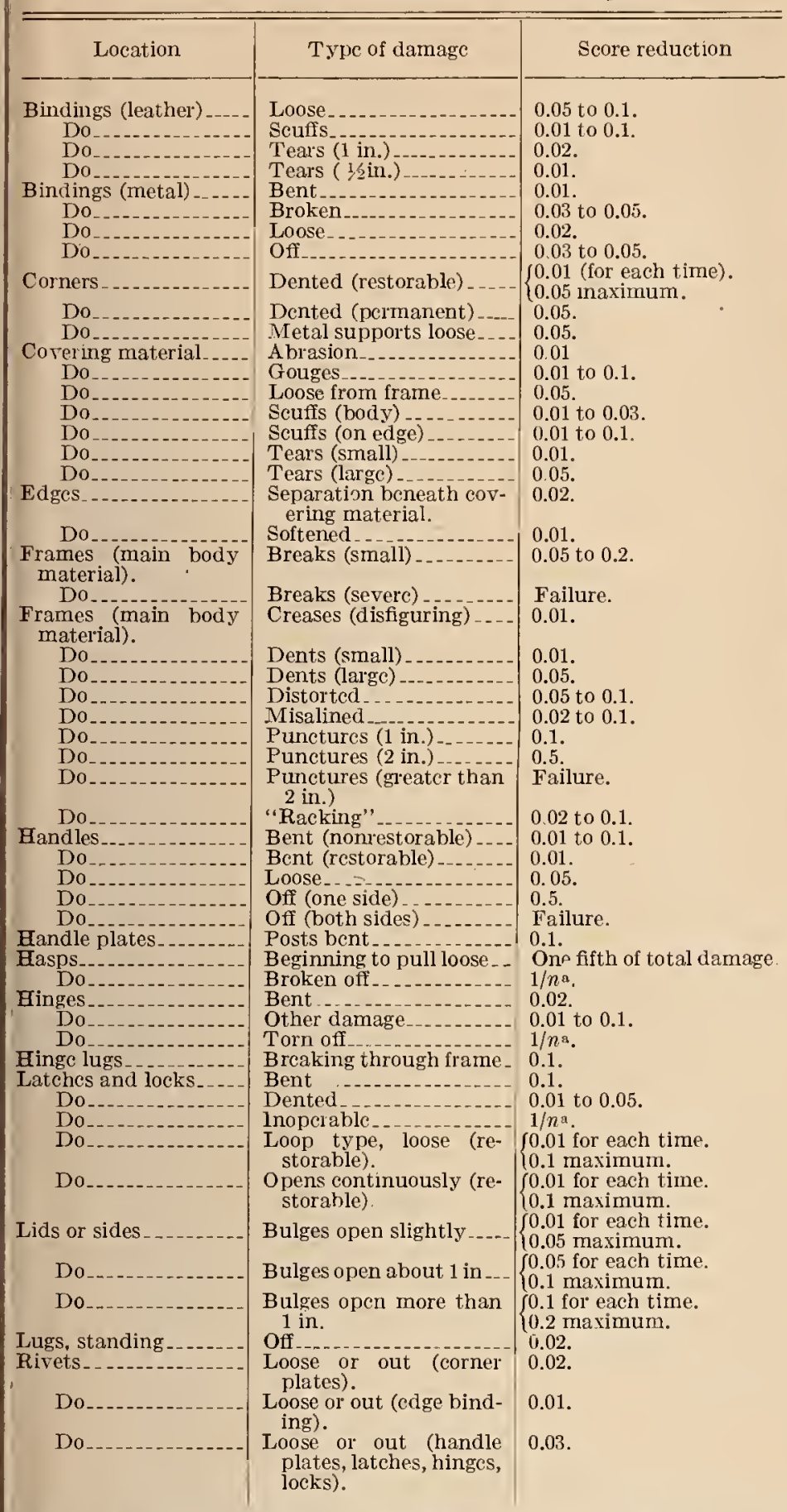

a $1 / n$ ( $n=$ total number hasps, hinges, locks, or latches present on bag.) For example, if a bag has two haspsand one lock, the score reduction for break. age of one hasp or one lock is $1 / 3$. If it has two hinges, tbe reduction for breakage of one hinge is $1 / 2$.

age to the handle, all these resulted in exposure of the contents, a condition that seems sufficient reason for listing the bag as a failure.

\section{(d) Puncture Test}

For this test the General Electric puncture tester was used. This device, shown in figure 18, has been in use for some time in testing paperboard shipping containers. ${ }^{4}$

4 Tentative Method of Test for Puncture and Stiffness of Paperboard, Corrugated and Solid Fiberboard, ASTM Designation D781-44T $\triangle$ STM Methods of Standards, part III, B, p. 1238 $(1946)$

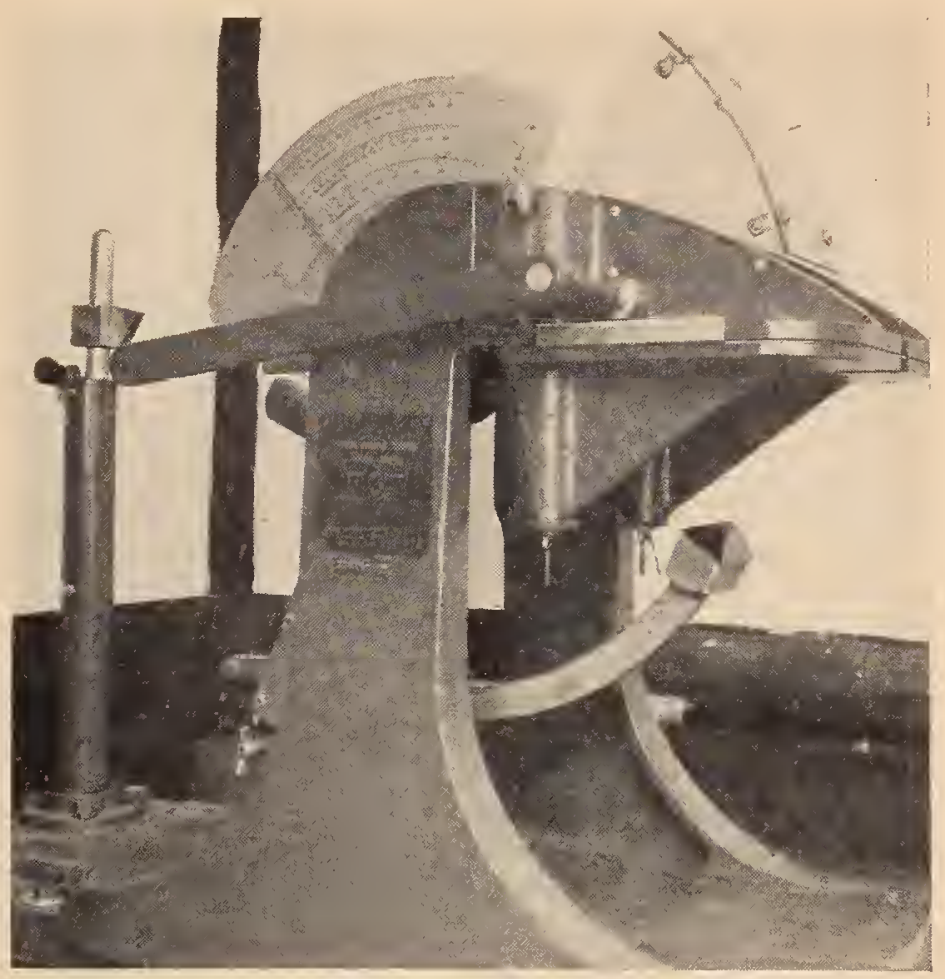

Figure 1S. Puncture test apparatus.

In making this test, the bag is dismantled, and the surfaces only, not the loaded bag, are used. Sides were punctured six times, ends once, and tops and bottoms twice. The results, in inchounces, were read from the scale. They were compared without correction for thickness.

\section{(e) Revolving Drum Test}

Preliminary tests of several specimens were made similarly to the "Tentative method of drum test for containers in small revolving hexagonal drum box-testing machine." 5 The loaded bag was placed in the drum, which contained a series of baffles and hazards, so arranged that when the drum revolves about its horizontal axis, the bag is subjected to successive falls in different positions.

The results of this test appeared to represent well the behavior that was to be expected or had been experienced for bags in actual service. However, since the cost of such a drum is rather large and it requires much laboratory space, and since substantially the same results are given by the divided-table drop tester, it was thought unnecessary to continue the study of the revolving drum at this time.

\section{Results and Discussion}

\section{(a) Handle Fatigue Test}

The results of handle fatigue tests are given in table 11 . 'The tests were discontinued at 50,000 pickups if no failure appeared.

5 ASTM Designation D T82-44T, ASTM Methods of Standards, part Ill, p. $1315(1944)$. 


\begin{tabular}{|c|c|c|c|c|}
\hline \multirow[b]{2}{*}{ Bag No. } & \multirow[b]{2}{*}{ Identification } & \multicolumn{2}{|c|}{ Number of pickups } & \multirow[b]{2}{*}{ Type of failure } \\
\hline & & $\begin{array}{c}\text { Bag not } \\
\text { subjected } \\
\text { to previous } \\
\text { test }\end{array}$ & $\begin{array}{c}\text { Bag prc- } \\
\text { viously } \\
\text { subjected to } \\
\text { drop test }\end{array}$ & \\
\hline & $\begin{array}{l}\text { Cbipboard, small. } \\
\text { Chipboard, large } \\
\text { Yulcanized fiberboard, small } \\
\text { Vuleanized fiberboard, large } \\
\text { Fibric-covered, lower-priced, small } \\
\text { Fabric-covered, lower-prieed, large } \\
\text { Fabric-covered, higher-prieed, small } \\
\text { Fabrie-coverer, higher-prieed, large } \\
\text { Plastic composition, sniall } \\
\text { Phastic composition, large } \\
\text { Leather, small } \\
\text { Leather, large. }\end{array}$ & $\begin{array}{r}37,470 \\
16,180 \\
50,000 \\
50,000 \\
50,000 \\
11,230 \\
13,260 \\
1,140 \\
50,000 \\
11,490 \\
50,000 \\
17,500\end{array}$ & $\begin{array}{l}17,920 \\
35,120 \\
50,000 \\
50,000 \\
50,000 \\
(1) \\
11,630 \\
5,830 \\
29,150 \\
26,780 \\
9,090 \\
(1)\end{array}$ & $\begin{array}{l}\text { Metal strip holding handle plate to ease pulled ont. } \\
\text { Do. } \\
\text { Do. } \\
\text { Reinforcing strip broke. } \\
\text { Do. } \\
\text { Posts spread, releasing pin. Reinfolcing strip broke. } \\
\text { Do. }\end{array}$ \\
\hline
\end{tabular}

1 Hiludle broken in previous test.

It is notable that seven of the fourteen observed failures were caused by fracture of the metal reinforcing strip passing through the handle. Five were caused by bent metal strips fastening the handle plate to the body of the bag becoming straightened out under continued stress, and pulling out of the bag.

The results strongly indicate that a satisfactory handle will withstand at least 25.000 pickups. 'Twelve of the 22 handles reported here were capable of this performance, and the majority of these rere found on inexpensive bags. Most of the failures were due to causes that would not be diflicult to remedy. It may seem that 25,000 pickups far exceed the number of times that a bag will be picked up during its lifetime, but if one consider's the vertical component of the fluctuating stresses received while the bag is carried by a pedestrian, the total number of up-and-down stresses may well be of the order of magnitude of 25,000. Certainly the number of handle failures occurring in actual service indicates that improvement in some bags is desirable, and this test points out improvements that could easily be effectuated.

\section{(b) Static Load Test}

Static load tests were made on only one set of the duplicates, as it was preferred not to strain all the bags prior to the drop tests.

Nine of the 12 bags tested were entirely satisfactory under these conditions of external loading. Even the flimsier cases were not complete failures. Application of the load to three bags, the small fiberboard and the small and large models of the chipboard resulted in some buckling and caving in of the structure. In this respect, these three bags must necessarily be rated somewhere lower than the others but not severely as the damage inflicted was not very serious. The loading caused no tear's or structural breaks but did result in marring the appearance of the cases, through creasing and slight distortion, which, of course, would not seriously affect the usefulness of a bag in service. Any bag failing to withstand this moderate degree of external loading would certainly not offer satisfactory performance in actual use where heavier loading and greater force of application of the load are likely to be encountered.

\section{(c) Divided-Table Drop Test}

In table 12 are listed the averages of scores of each set of duplicates for the various styles, resulting from the divided-table drop test. It is to be noted that in all instances except one, the average score of thie larger sizes is less than for the corresponding smaller sizes. In the case of the exception, the score is practically the same for both sizes. The results indicate that large-sized cases are much more prone to suffer damage on dropping than are small cases.

The chipboard cases received the lowest average drop rating. The poor construction and inherently weak materials of which they were composed were the responsible factors. The fabric-covered bags were some what stronger and resisted damage thronghout the dropping slightly better than the chipboard.

Table 12. Results of drop tests-score values

\begin{tabular}{|c|c|c|}
\hline Bag No. & Identification of bag & Score \\
\hline 1. & Chipboard, small & 30.2 \\
\hline 2. & Chipboard, large & 25.2 \\
\hline 3. & Vulcanized fiberboard, small.... & 139.4 \\
\hline 4. & Vulcanized fiberboard, large & 119.6 \\
\hline & Fabric-covered, lower-priced, small & 84.5 \\
\hline 6. & Fabric-eovered, lower-priced, large $\ldots \ldots \ldots \ldots \ldots$ & 20.0 \\
\hline & Fabric-covered, higher-priced, small & 53.2 \\
\hline & Fabr ie-covered, higher-priced, large.............. & 57.6 \\
\hline 9 & Plastic-eovered, small .............................. & 96.7 \\
\hline $10_{-}$ & Plastic-covered, large & 73.6 \\
\hline 11 & Leather-eovered, small _... & 58.7 \\
\hline 12 & Leather-covered, large & 23.0 \\
\hline
\end{tabular}

The factor contributing chiefly to their breakage was failure of the hardware, particularly the hasps, spot-melded, and the insert type. Frame breaks probably ranked second in cause of failures and low scores. On dropping, the small 
metal fasteners, which bind the leather edge binding and protect the edges of the cases, work loose. They are generally held by two bifurcated rivets, which are easily loosened from the frame (pinewood) and in turn permit the leather binding to be detached. The joints of the two adjoining faces then separate, and the case is ruined. Some more durable method of fastening the bindings is strongly recommended.

The liandles of these fabric-covered cases, as well as those of the leather cases, stood up poorly also in the drop tests. The hollow uprights, which hold the pins supporting the handle, spread on dropping the case on the No. 2 face (handle face) and permit the pin to become dislodged from the holes. The handle then tears off. In some instances the metal, which passes through the frame and which holds the handle plate attached to the frame, loosens because of the cropping, and pulls loose. The metal is quite soft and can be straightened out by hand with little effort.

The highest scores were made by the vulcanized fiberboard and the plastic-coated cases. Both types have proven themselves quite damage-resistant in actual service, according to baggage handler's. The chief fault of the fiberboard was one of distortion of the structure as the test progressed, which would probably allow loss of some small items in actual service if comparable damage were inflicted. This happened as the dropping was made from greater heights and after the bags had been dropped a large number of times. These bags can withstand quite a number of drops before showing frame distortion and are almost indestructible in this test insofar as crushing, tearing, and frame breaks are concerned. The rivets, which form the edge seams and also hold the hardware, are exceptionally hard and resistant toward pulling loose.

The plastic-covered cases received lower scor'es mainly because of the latches and locks. Being of a different, external-tension snap-over-type construction than the loop snap-over type of the fiberboards, they were more easily misalined. Slightly misalined, they no longer hold, and the entire contents of the cases are spilled. Somewhat less serious is the distortion of the cases due to the nonfit of the tongue and groove edges of the lid and body components caused by severe dropping. As in the case of the fiberboards, this distortion also takes place only after a large number of drops. One peculiar difference was noted between the large and small models. The latter had higher standing lugs (about one-quarter inch taller), a part of the sturdy back hinge. which in several instances caused the surrounding frame wood of the side 4 to fracture when dropped on this face.

The damages observed by dropping the bags seem to correspond closely to the types of damage observed on baggage during the surveys. It is surmised that most damage is inflicted in this manner. The determination of the resistance to damage of a bag on dropping gives a fairly reliable estimate of how well a bag will endure the stresses of arerage travel. These results on the divided table tester indicate that a ba $\underline{\text { should be }}$ able to amass a score of $50 \mathrm{in}$ order to be classified as satisfactory for service. These points are discussed further in section $\mathrm{V}$, service tests.

Figures 4, B, to $15, \mathrm{~B}$, show typical damage occurring to each test specimen during the drop test. Only the two handle failures in $9, \mathrm{~B}$, and $15, \mathrm{~B}$, were due to the dropping, the others having been damaged on the handle fatigue test.

\section{(d) Puncture Tests}

Although the results of the puncture tests indicate that this method may be useful after further development, the data so far obtained are insufficient to justify a recommendation for its inclusion in a commercial standard. Of the 12 bags tested, eight had puncture resistance close to, or beyond the capacity of the instrument, readings of 1,300 to 1,350 inch-ounces being obtained. These specimens were mostly of three-ply veneer construction. Usually the swinging head fractured the specimen but did not completely penetrate it. It is thought that a modified apparatus with perhaps twice the capacity would be useful.

Only the chipboard cases showed rery low resistance to puncture, yielding readings of 210 - and 227 -inch-ounces. One of the fiberboard cases gave a value of 667 inch-ounces, and one of the lowerpriced fabric-covered cases punctured at 1,002 inch-ounces. The beharior of these materials in service indicates that a puncture resistance in the neighborhood of 225 inch-ounces is too low, and that a value of 1,300 inch-ounces is satisfactory, but no intermediate fiducial limit can be set with a satisfactory degree of assurance.

\section{Service Tests}

\section{Plan of Tests}

In order to compare and correlate laboratory behavior with service performance, a replicate of each of the types tested in the laboratory was sent through regular railroad baggage clecking service from Washington, D. C.. to various cities and return. Eleven destinations were selected so as to require much handling of the bags because of transfer points en route. The samples were identified by the customary check number's only, and every effort was made to make the shipment ap- 
pear as normal as possible in order to prevent any biased handling. The itinerary of the eleven trips was repeated once. On each retmrn, the cases were cxamined carefully and records kept of their condition. 'They were then sent over' another route. The bags were shipped out altermately locked, half-locked, and unlocked. Some bags land only one lock and were therefore sent locked and unlocked. 'The total number' of miles traveled by the bags was abont 12,000 , during which they sustained abont $2+$ handlings per round trip. A system for scoring the bags similar to the one used with the divided-table drop tester, was helpful for an evaluation of the bags after the service tests had been completed.

\section{Results}

Twenty-two round trips resulted in severe damage to six of the 12 specimens. The damage sustained by the six bags was severe enough to classify the bags as failures or as damage-claim luggage. Table 13 lists the types of damage occurring to the cases. In instances where several major damage items are mentioned for one bag, the first item is the primary cause of the damage, the other damage occurring because the bag was left in service to obtain auxiliary information. The trip numbers designate the trip on which the bag failed. The scores represent a numerical comparing system, calculated from the data in a manner similar to that used in the drop tests.

TABLE 13. Results of service tests

\begin{tabular}{|c|c|c|c|c|c|}
\hline$\underset{\text { ber }}{\text { Bag num- }}$ & Identification & Score & $\begin{array}{l}\text { Number } \\
\text { of round } \\
\text { trifs }\end{array}$ & Major dalnage & Minor damage \\
\hline & Chipboard, small.. & 2.0 & 3 & Handle failurc; large tear....... & Small tears of covering. \\
\hline & Chipboard, large ........... & 1. 0 & 2 & Large puncture; liandle failure. & Softening of case; small puncture; small tears. \\
\hline 3 & Vulcanized fiberboard, small ... & 20.0 & 22 & Nolle & $\begin{array}{l}\text { Lock opened after each trip; abrasion malks plentiful; } \\
\text { very sliglit seuffs. }\end{array}$ \\
\hline 4 & Vulcanizer fiberboard, large & 23. 1 & 22 & -...-. do.. & Lock opencd frequently; considerably marked up \\
\hline & $\begin{array}{l}\text { Fabric-covered, lower-priced, } \\
\text { small. }\end{array}$ & 21.0 & 22 & do & $\begin{array}{l}\text { Leathel severcly scufted; separation of edges bencath } \\
\text { fabric. }\end{array}$ \\
\hline & $\begin{array}{l}\text { Fabrie-covered, lower-priced, } \\
\text { large. }\end{array}$ & 3.0 & 5 & $\begin{array}{l}\text { Handle failure; spot-welded hasp } \\
\text { broken. }\end{array}$ & $\begin{array}{l}\text { Severe scuffing of leather binding; small dents in } \\
\text { sides. }\end{array}$ \\
\hline & $\begin{array}{l}\text { Fabrie-covered, higher-priced, } \\
\text { sinall. }\end{array}$ & 21.8 & 22 & None & $\begin{array}{l}\text { Separation of edges leneath fabric; moderate scuffing } \\
\text { of leather binding; loose rivets. }\end{array}$ \\
\hline & $\begin{array}{l}\text { Fabric-eovered, higher-priced, } \\
\text { large. }\end{array}$ & 13.6 & 22 & $\begin{array}{l}\text { Frame break on lid edges } 5 \text { and } \\
6 \text {; hinge sidc } 4 \text { broken. }\end{array}$ & $\begin{array}{l}\text { Handle plate and pins damaged, loose edges beneath } \\
\text { fabrie; leather binding scuffed. }\end{array}$ \\
\hline & I'lastic-covered, small $\ldots \ldots \ldots$ & 20.5 & 22 & None & $\begin{array}{l}\text { Scuffing of plastic coating; hinge lugs penetrated } \\
\text { coating. }\end{array}$ \\
\hline 10. & Plast ic-covered, large & 21.9 & 22 & -.... do & $\begin{array}{l}\text { Scuffing of plastic coating; temporarily misalined; } \\
\text { ccnter latch inoperative. }\end{array}$ \\
\hline 11. & Leather-covered, small & 16.2 & 22 & Puncture _.. & Severe ovèrall scuffing; partial hinge break; separation \\
\hline $12 \ldots$ & Lcather-eovered, large.- & 3. 9 & 5 & Handle failure - & $\begin{array}{l}\text { Severe overall scuffing; some edge separation beneath } \\
\text { leather. }\end{array}$ \\
\hline
\end{tabular}

The types of damage responsible for failures were punctures, one; tears, one; handle failures, three; and frame breaks, one. The additional major types of damage mentioned were not the primary cause of the failure. For example, the large chipboard case failed on the trips because of a large tear. The handle on the same bag broke while it was being returned to the laboratory. The small model of the same material failed primarily because of a broken handle. Substitution of another handle resulted in a tearing of the surface chipboard. The other cases suffering handle failur'es could not be continued in the tests as the damage was not repairable.

The structurally weak bags broke early in the tests and consequently received lower ratings. The other bags varied in the amount of damage they sustained throughout the tests. The fabriccovered and leather-covered cases were bruised and scarred appreciably. They are, therefore, intermediate between the chipboards and the plastic-covered and vulcanized fiberboards. The latter two types of bags endured the testing admirably and therefore have high scores. Very little happened to them aside from slight scuffing and marling. The small plastic-coated bag, however, was beginning to show the same effect from the high hinge lug as was evidenced in the drop tests.

Larger cases again, as in the drop tests, were more vulnerable to injury than the small bags except for the plastic-covered and vulcanized fiberboard cases. These bags were built to accommodate the heavier loads that would naturally be placed in large size luggage.

The types and extent of damage occurring during the service tests are shown in figures $4, \mathrm{C}$, to $15, \mathrm{C}$, in the same order as they appear in table 13. 


\section{Conclusions}

\section{Correlation of Laboratory and Service Tests}

The data, though limited in number, indicate that the results of the laboratory tests, especially those pertaining to the handle fatigue and divided-table drop tests, correlate well with the results obtained during the actual service tests. These two laboratory tests duplicate quite well the damage observed during the survey in rail and bus baggage rooms.

It has been shown by the laboratory drop test that the large-sized cases break more frequently than the smaller cases. Table 12 shows this to be true five times out of six based on the average scores of duplicate samples. In service tests, table 13, the same is true four times out of six based on single replicate samples. In the handle fatigue test, in five out of six comparisons of duplicate specimens, the handles of the small bags held up best. The average number of pickups of all the handles of small bags was approximately 35,000 as against approximately 23,000 pickups for all the handles of large bags. In service, four handle breaks were obtained, and three of them were on the large-sized cases.

If size is disregarded and the average scores for the service test samples are compared with scores of the table drop-test method, the rank rating is identical, as is shown in table 14 .

TABLE 14. Correlation between results of service and laboratory tests

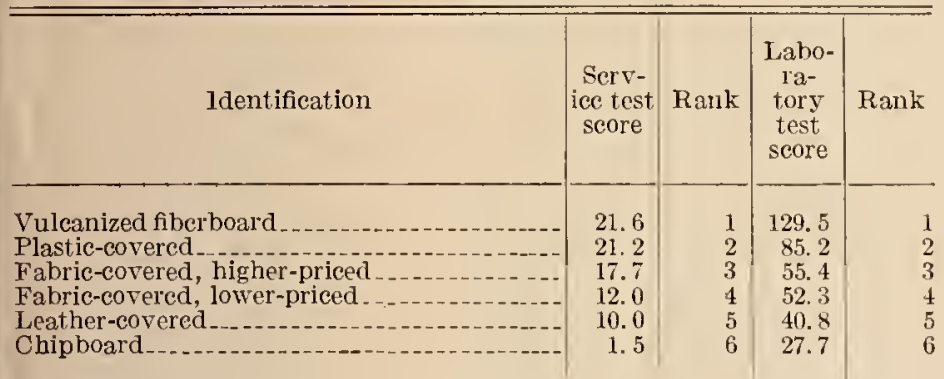

The correlation, therefore, between service and laboratory tests, insofar as material, hardware, and construction are involved, is excellent.

No permanent incapacitating effect was produced by externally loading the bags in the laboratory. No truly crushed or flattened cases were had through the service tests. It might be said that the results compare similarly. Only two severe punctures were had in the service testing, one on a bag showing high puncture resistance on the puncture tester, and the other on a bag showing low puncture resistance on the same instrument. The results are, therefore, inconclusive.

\section{Recommended Requirements}

In view of the data presented, the following recommendations are offered for estimating the performance that might be expected of any given bag when placed in service. The recommendations apply to bags only of the rigid type. The bags should be loaded in accordance with the recommended weighting shown in table 9, except where noted.

A. The empty specimen shall have placed successively on its lid side (side No. 1), its top side (side No. 2), and its end (side No. 5), a 150-pound weight for a time interval of 5 minutes in each position. The surface area of the weight in contact with the bag shall be approximately 5 by $\delta$ inches.

The bag shall show no. structural failure, tears, permanent crushing, or irreparable damage.

B. The loaded specimen shall be subjected to the action of an apparatus capable of picking up a bag by the handle and setting it down repeatedly. The apparatus shall pick up and set down the bag at a rate of approximately 37.5 times per minute and shall exert a peak force of 1.8 times gravity when tested against a 50-pound weight.

The bag shall be capable of withstanding 25,000 pickup motions of the machine.

C. 'The loaded specimen shall be dropped successively on all its faces, edges, and corners from a drop-tester, which meets the requirements outlined in the ASTM Tentative Designation (D775-45T). The initial height of fall shall be $1 \frac{1}{2}$ feet and shall be progressively increased by 6 -inch increments until the total fall height is 5 feet or until failure occurs. The specimen shall be dropped on each face, edge, and corner, from each height. Records shall be made of the effect of each fall. Each fall shall be evaluated with a numerical score, the value of which shall be commensurate with the damage.

The summation of the scores for all falls shall total 50 or greater to indicate satisfactory resistance to dropping.

D. Some standard form of label or pocket insert card should be placed inside new luggage, as a means of identification of the ownership to help avoid loss of the bag if the baggage check becomes detached along with a faulty handle.

The authors thank officials of the Pennsylvania Railroad for making possible the service tests and for other assistance; the staff of the Washington Terminal for checking out and recalling the samples in service tests; and officials of the New York, New Haven \& Hartford Railroad, the American 
Airlines, the Penmsylymia Greyhomed and Floridal Greyhound Bus Lines, the Mtlantic Coast Line Railroad, the Seaboard lir Line Railroad, and the ('hicago \& Northwestern Raiload for permission to make surveys and for their help in conducting them.

'I'he assistance of oflicer's of the National Trooden Box Association in the selection of test plocedures and in providing some laboratory facilities is also gratefully acknowledged.

'The following member's of the staff of the $\mathrm{Na}$ tional Bureau of Standards contributed muchappreciated assistance and suggestions: A. S. Best. John Mandel, C. E. Weir, C. W. Mann, and Rene Oehler.

Trasmingron, February 2, 1949. 